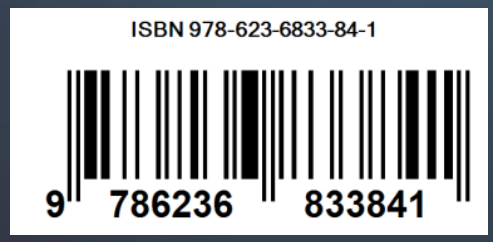

UNSIDA Press

Universtas Muhammadiyah Sidoarjo 11. Nojopshit 666 B Sidoarjo Sidoarja, Jawa Timur
Bayu Hari Prasojo, S.Si., M.Pd. Novia Ariyanti, S.Si.) M.Pd.

UMSIDA

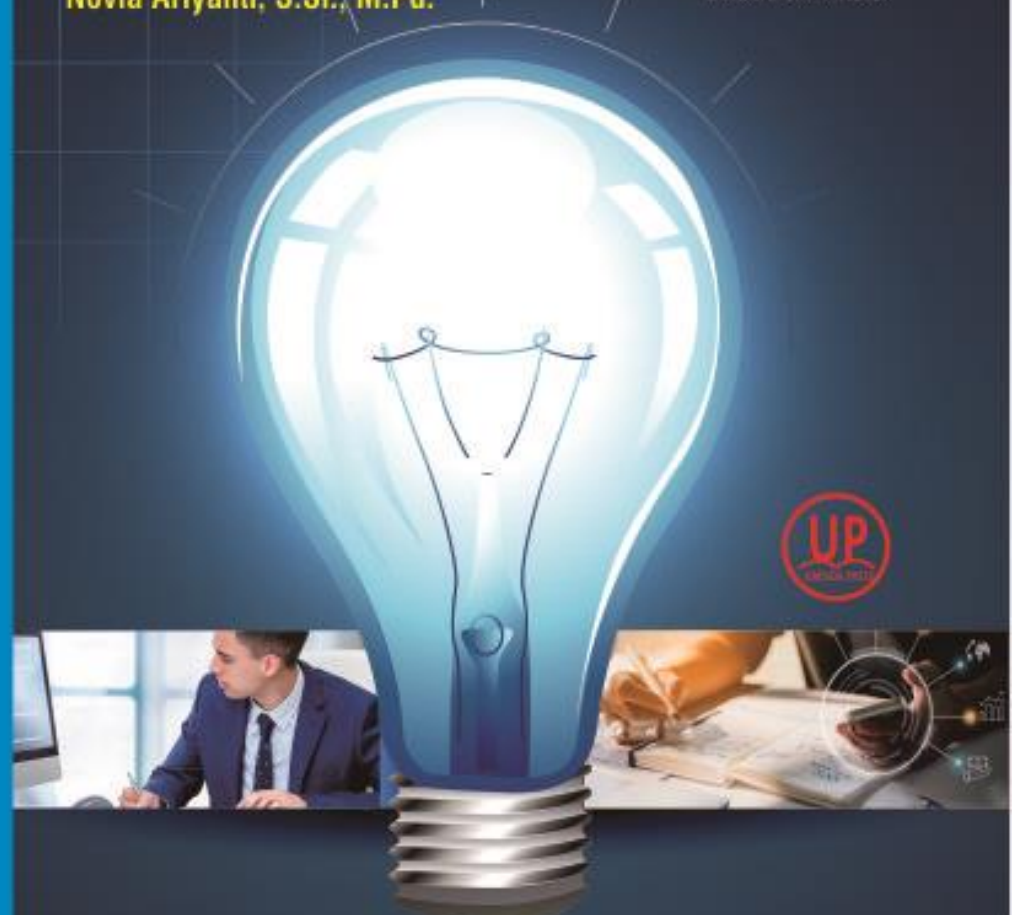

Statistik Bisnis 


\title{
BUKU AJAR STATISTIK BISNIS
}

\author{
Oleh \\ Bayu Hari Prasojo, S.Si., M.Pd. \\ Novia Ariyanti, S.Si., M.Pd.
}

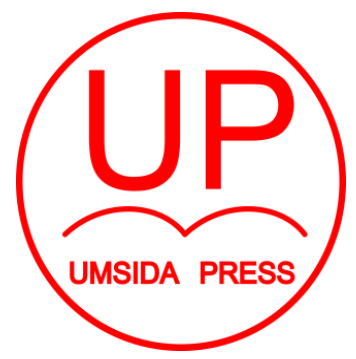




\section{BUKU AJAR \\ STATISTIK BISNIS}

\section{Penulis:}

Bayu Hari Prasojo, S.Si., M.Pd.

Novia Ariyanti, S.Si., M.Pd.

\section{ISBN :}

978-623-6833-84-1

\section{Editor:}

Sumartik, SE., MM.

\section{Design Sampul dan Tata Letak:}

Mochammad Nashrullah, S.Pd.

Amy Yoga Prajati, S.Kom.

Penerbit:

UMSIDA Press

Anggota IKAPI No. 218/Anggota Luar Biasa/JTI/2019

Anggota APPTI No. 0020181092017

Redaksi

Universitas Muhammadiyah Sidoarjo

Jl. Mojopahit No 666B

Sidoarjo, Jawa Timur

Cetakan Pertama, September 2020

CHak Cipta dilindungi undang undang

Dilarang memperbanyak karya tulis ini dengan sengaja, tanpa ijin tertulis dari penerbit. 


\section{KATA PENGANTAR}

Puji syukur kami panjatkan kehadirat Allah SWT, atas rahmat dan karunia-Nya Buku Ajar Statistik Bisnis dapat diselesaikan dengan baik dan tanpa halangan yang berarti. Shalawat dan salam selalu kami sampaikan kepada junjungan Nabi Muhammad SAW.

Tim penulis mengucapkan terimakasih kepada:

1. Wisnu Panggah Setiyono, SE., M.Si., Ph.D, Dekan Fakultas Bisnis, Hukum dan Ilmu Sosial yang memberikan arahan dan motivasi kepada penulis dalam menyelesaikan buku ajar ini.

2. Dewi Komala Sari, SE., MM., Kaprodi Manajemen yang telah memberikan dukungan untuk menyusun buku ajar ini.

3. Rekan-rekan dosen pengampu Mata Kuliah Statistik Bisnis di prodi Manajemen yang telah berbagi pengalaman dalam mengampu mata kuliah tersebut.

Saran dan kritik sangat penulis harapkan untuk mewujudkan buku ajar Statistik Bisnis yang lebih baik dan tentunya sesuai dengan amanat peraturan yang berlaku. Terimakasih. 


\section{DAFTAR ISI}

Kata Pengantar ...................................................................... i

Daftar Isi ................................................................................. ii

BAB 1 Pendahuluan Mengenai Statistik ............................... 1

A. Pendahuluan ................................................................ 1

B. Penyajian Materi ......................................................... 5

BAB 2 Distribusi Frekuensi .......................................................... 10

A. Pendahuluan ........................................................ 10

B. Penyajian Materi ....................................................... 11

1. Tahap Penyusunan Distribusi Frekuensi ............... 11

2. Histogram, Poligon dan Ogive .............................. 14

C. Latihan ..................................................................... 17

BAB 3 Statistik Deskriptif ........................................................ $\quad 20$

A. Pendahuluan ........................................................... 20

B. Penyajian Materi ....................................................... 20

1. Mean .................................................................. 20

2. Median ................................................................ 22

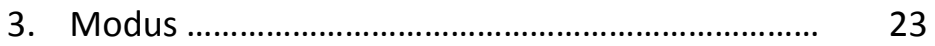

4. Kuartil .................................................................. 24

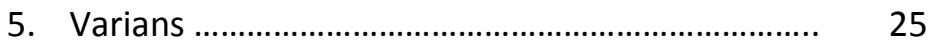

6. Standar Deviasi .................................................. 26

7. Diagram Lingkaran .............................................. 27

C. Latihan ................................................................... $\quad 38$

BAB 4 Probabilitas ................................................................ 40

A. Pendahuluan ............................................................ 40

B. Penyajian Materi ........................................................ 40

1. Pengertian Probabilitas ....................................... 40

2. Manfaat Probabilitas ............................................. 41 
3. Pendekatan Probabilitas......................................... 42

4. Aturan-aturan dalam Probabilitas ....................... 45

5. Teori Bayes ........................................................... 52

C. Latihan ................................................................. 54

BAB 5 Angka Indeks ......................................................... 56

A. Pendahuluan ............................................................. 56

B. Penyajian Materi ...................................................... 57

1. Jenis-jenis Angka Indeks ....................................... 57

2. Metode Perhitungan Angka Indeks ..................... 60

C. Latihan ..................................................................... $\quad 75$

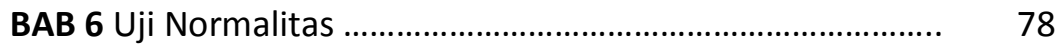

A. Pendahuluan .......................................................... $\quad 78$

B. Penyajian Materi ........................................................ $\quad 78$

C. Latihan ........................................................................ 82

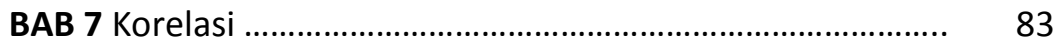

A. Pendahuluan ............................................................. 83

B. Penyajian Materi .......................................................... 84

1. Statistik Parametrik ................................................. 84

2. Statistik Non Parametrik ..................................... 88

C. Latihan .................................................................. 99

BAB 8 Regresi Linier .................................................................. 101

A. Pendahuluan ................................................................ 101

B. Penyajian Materi ........................................................ 101

1. Regresi Linier Sederhana ..................................... 101

2. Regresi Linier Berganda ..................................... 104

C. Latihan ................................................................... 106

BAB 9 Pengujian ANOVA ............................................................ 108

A. Pendahuluan .............................................................. 108 
B. Penyajian Materi ...................................................... 108

C. Latihan .................................................................. 114

Daftar Pustaka ..................................................................... 115

Biodata Penulis 
BATANG TUBUH \& SUB-CAPAIAN PEMBELAJARAN MK

\begin{tabular}{|c|c|}
\hline BAB & Sub-Capaian Pembelajaran Mata Kuliah \\
\hline $\begin{array}{l}\text { BAB I } \\
\text { PENDAHULUAN } \\
\text { MENGENAI } \\
\text { STATISTIK }\end{array}$ & $\begin{array}{l}\text { 1. Mahasiswa mampu memahami Arti dan Kegunaan } \\
\text { Data } \\
\text { 2. Mahasiswa mampu menentukan Syarat Data yang } \\
\text { Baik } \\
\text { 3. Mahasiswa mampu memahami Pembagian Data } \\
\text { 4. Mahasiswa mampu memahami Definisi Statistik } \\
\text { 5. Mahasiswa mampu menjelaskan Peranan Statistik } \\
\text { bagi Dunia Bisnis } \\
\text { 6. Mahasiswa mampu memahami Teknik Pengumpulan } \\
\text { Data } \\
\text { 7. Mahasiswa mampu memahami Teknik Pengolahan } \\
\text { Data }\end{array}$ \\
\hline $\begin{array}{l}\text { BAB II } \\
\text { DISTRIBUSI } \\
\text { FREKUENSI }\end{array}$ & $\begin{array}{l}\text { 1. Mahasiswa mampu menyusun Tabel Distribusi } \\
\text { Frekuensi. } \\
\text { 2. Mahasiswa mampu memahami Bentuk-bentuk } \\
\text { Penyajian Data. }\end{array}$ \\
\hline $\begin{array}{l}\text { BAB III } \\
\text { STATISTIK } \\
\text { DESKRIPTIF }\end{array}$ & $\begin{array}{l}\text { 1. Mahasiswa mampu menentukan Mean / Rata-rata } \\
\text { Hitung } \\
\text { 2. Mahasiswa mampu menentukan Median } \\
\text { 3. Mahasiswa mampu menentukan Modus } \\
\text { 4. Mahasiswa mampu menginterpretasikan Hubungan } \\
\text { antara Mean, Median dan Modus } \\
\text { 5. Mahasiswa mampu menentukan Kuartil dan Desil } \\
\text { 6. Mahasiswa mampu memahami Makna dan Kegunaan } \\
\text { Standar Deviasi }\end{array}$ \\
\hline $\begin{array}{l}\text { BAB IV } \\
\text { PROBABILITAS }\end{array}$ & $\begin{array}{l}\text { 1. Mahasiswa mampu memahami pengertian } \\
\text { probabilitas. } \\
\text { 2. Mahasiswa mampu memahami manfaat probabilitas } \\
\text { dalm kehidupan sehari-hari. } \\
\text { 3. Mahasiswa mampu menentukan pendekatan dalam } \\
\text { probabilitas. }\end{array}$ \\
\hline
\end{tabular}




\begin{tabular}{|c|c|}
\hline & $\begin{array}{l}\text { 4. Mahasiswa mampu menerapkan aturan-aturan } \\
\text { probabilitas dalam pemecahan masalah bisnis. }\end{array}$ \\
\hline $\begin{array}{l}\text { BAB V } \\
\text { ANGKA INDEKS }\end{array}$ & $\begin{array}{l}\text { 1. Mahasiswa mampu memahami jenis-jenis angka } \\
\text { indeks. } \\
\text { 2. Mahasiswa mampu melakukan penghitungan angka } \\
\text { indeks } \\
\text { 3. Mahasiswa mampu menginterpretasikan hasil } \\
\text { perhitungan angka indeks }\end{array}$ \\
\hline $\begin{array}{l}\text { BAB VI } \\
\text { UJI } \\
\text { NORMALITAS }\end{array}$ & $\begin{array}{l}\text { 1. Mahasiswa mampu memahami konsep uji } \\
\text { normalitas. } \\
\text { 2. Mahasiswa mampu melakukan perhitungan uji } \\
\text { normalitas chi kuadran. } \\
\text { 3. Mahasiswa mampu menganalisa hasil dari uji } \\
\text { normalitas. }\end{array}$ \\
\hline $\begin{array}{l}\text { BAB VII } \\
\text { KORELASI }\end{array}$ & $\begin{array}{l}\text { 1. Mahasiswa mampu memahami jenis-jenis korelasi. } \\
\text { 2. Mahasiswa mampu memahami konsep statistic } \\
\text { parametric. } \\
\text { 3. Mahasiswa mampu memahami konsep statistic non } \\
\text { parametrik } \\
\text { 4. Mahasiswa mampu melakukan pengujian korelasi }\end{array}$ \\
\hline $\begin{array}{l}\text { BAB VIII } \\
\text { REGRESI }\end{array}$ & $\begin{array}{l}\text { 1. Mahasiwa mampu memahami Hubungan Fungsional } \\
\text { antara Variabel } \\
\text { 2. Mahasiswa mampu menentukan persamaan regresi } \\
\text { linier sederhana } \\
\text { 3. Mahasiswa mampu menentukan persamaan regresi } \\
\text { linier berganda }\end{array}$ \\
\hline $\begin{array}{l}\text { BAB IX } \\
\text { PENGUJIAN } \\
\text { ANOVA }\end{array}$ & $\begin{array}{l}\text { 1. Mahasiswa mampu memahami Analisa Variansi Satu } \\
\text { Arah } \\
\text { 2. Mahasiswa mampu memahami Teknik Analisa } \\
\text { Varians } \\
\text { 3. Mahasiswa mampu menggunakan tabel Analisa } \\
\text { Varians }\end{array}$ \\
\hline
\end{tabular}




\section{BAB I}

\section{PENDAHULUAN MENGENAI}

\section{STATISTIK}

\section{A. PENDAHULUAN}

Dalam pengertian secara sempit, statistik diartikan sebagai kumpulan data yang menjelaskan sesuatu atau juga dapat diartikan sebagai parameter. Namun, dalam pengertian secara luas statistik merupakan Ilmu yang mempelajari tentang cara pengumpulan data, pengolahan data, penyajian data dan menganalisis serta menginterpretasikan data yang pada akhirnya akan digunakan dalam pengambilan keputusan.

Statistik banyak digunakan dalam berbagai bidang. Untuk bidang ekonomi dan bisnis, beberapa diantaranya adalah :

1. Bidang Akuntansi (Accounting)

Perusahaan akuntan publik seringkali menggunakan prosedur pengambilan sampel (contoh) yang memenuhi kaidah-kaidah statistik ketika melakukan audit terhadap kliennya.

2. Bidang Keuangan (Finance)

Penasehat keuangan menggunakan berbagai jenis informasi statistik, termasuk rasio keuangan price-earnings ratio dan hasil dividen, untuk membantu dalam memberikan rekomentasi investasi.

3. Bidang Pemasaran (Marketing) 
Pengambilan sampel masyarakat sebagai calon konsumen untuk diminta pendapat tentang produk yang akan diluncurkan oleh suatu perusahaan seringkali menggunakan kaidah statistik.

\section{Bidang Ekonomi}

Para ahli ekonomi menggunakan prosedur statistik dalam melakukan peramalan tentang kondisi perekonomian pada masa yang akan datang.

5. Bidang Penelitian Ekonomi dan Bisnis

Pada bidang penelitian statistik digunakan sebagai alat pengolah data, penelitian yang menggunakan statistik adalah jenis penelitian kuantitatif. Penelitian sendiri adalah suatu cara ilmiah untuk mengambil kesimpulan dengan jalan mengumpulkan data dan mengolah data dengan menggunakan statistik, yang selanjutnya disimpulkan untuk tujuan dan kegunaan tertentu.

Data merupakan unsur yang paling penting dalam suatu penelitian. Data tidak dapat dibaca sebagai kesimpulan apabila tidak dilakukan pengolahan statistik. Penelitian di bidang ekonomi dan bisnis ini diantaranya adalah penelitian tentang tingkat kepuasan konsumen, penelitian tentang kinerja keuangan perusahaan dan lain sebagainya.

Dalam penelitian dalam bidang ekonomi dan bisnis terdapat dua jenis analisis yang digunakan, yaitu :

a. Pengujian Deskriptif

Pengujian yang memiliki tujuan mendeskripsikan atau memberi gambaran terhadap obyek yang diteliti melalui data sampel atau populasi. Data yang diolah dalam statistik 
deskriptif ini hanya terdiri dari satu variable saja. Pada statistik deskriptif yang dihasilkan berupa mean, median, modus, kuartil, tabel, grafik dan diagram.

b. Pengujian Inferensi

Pengujian yang membandingkan dua variabel atau lebih.

Pengujian Inferensi dapat dibagi menjadi tiga, yaitu :

1) Pengujian Hubungan (korelasi)

2) Pengujian Pengaruh (regresi)

3) Pengujian Perbedaan (paired sampel t-test, independent sampel t-test, dan lain sebagainya).

Statistik Inferensi dapat dikelompokkan menjadi dua, yaitu :

1) Statistik Parametrik

Statistik parametrik digunakan dengan syarat data sebagai sampel harus berdistribusi normal (diuji dengan menggunakan uji normalitas terlebih dahulu). Pengujian yang digunakan dalam statistik parametrik adalah :

a) Uji Perbedaan

Uji perbedaan dilakukan untuk menguji apakah sebuah sampel mempunyai perbedaan nyata dengan sampel yang lain. Uji yang digunakan adalah independent sampel t test, paired sampel t test, dan one sampel t-test.

b) Uji Hubungan

Uji hubungan dilakukan untuk menguji apakah dua variabel yang ada mempunyai hubungan. Uji yang digunakan adalah korelasi product momen Pearson. 


\section{c) Uji Pengaruh}

Uji pengaruh dilakukan untuk menguji apakah ada pengaruh antara variabel satu dengan variabel yang lain. Uji yang digunakan adalah regresi.

\section{2) Statistik Non Parametrik}

Statistik non parametrik digunakan pada kondisi-kondisi penelitian tertentu. Kondisi yang sering dijumpai antara lain : data pada sampel tidak terdistribusi normal, jumlah sampel yang kecil (kurang dari 30), cenderung lebih sederhana sehingga kesimpulannya kadang diragukan. Pengujian yang digunakan dalam statistik non parametrik adalah :

a) Uji Perbedaan

Uji perbedaan dilakukan untuk menguji apakah sebuah sampel mempunyai perbedaan nyata dengan sampel yang lain. Uji yang digunakan adalah Uji Sign, Uji Mann Whitney, Uji Friedman, Uji Kruskal Wallis.

b) Uji Hubungan

Uji hubungan dilakukan untuk menguji apakah dua variabel yang ada mempunyai hubungan. Uji yang digunakan adalah korelasi Spearman, Kendall Tau, koefisien Contingensi. 


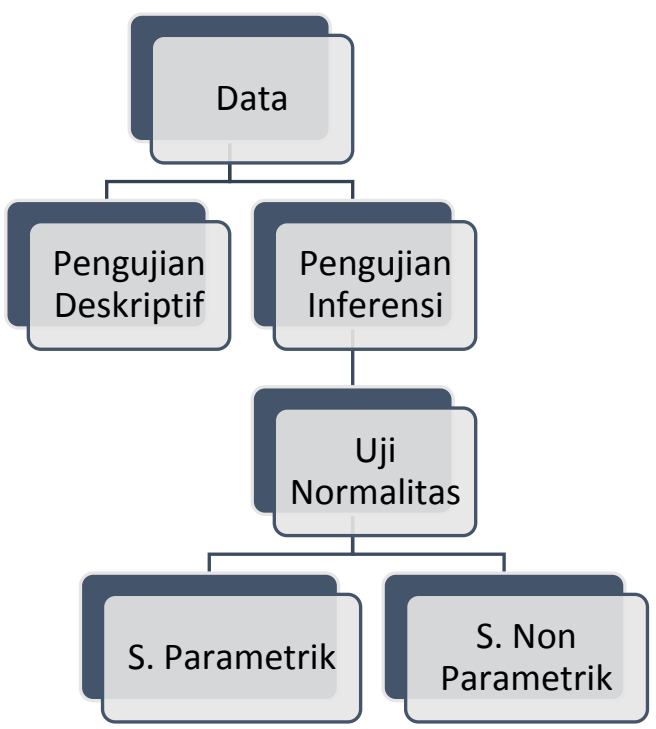

\section{Gambar 1.1 Ikhtisar Pembagian Fase Statistik}

Apabila data yang diperoleh dari penelitian berdistribusi normal maka uji inferensi yang digunakan adalah uji statistik parametrik, dan apabila data tidak berdistribusi normal maka yang digunakan adalah uji statistik non parametrik.

\section{B. PENYAJIAN MATERI}

Dalam Statistik ada tiga hal yang sangat penting, yaitu :

a. Data dan variabel

Data merupakan kumpulan keterangan atau fakta yang dapat berbentuk kategori (non numerik) ataupun bilangan (numerik) 
yang dikumpulkan kemudian diolah menjadi informasi yang nantinya berguna dalam menentukan keputusan.

Variabel adalah karakteristik data yang menjadi perhatian. Variabel dibedakan menjadi dua yaitu variabel diskrit dan variabel kontinu. Variabel diskrit adalah variabel suatu variabel dengan nilai yang dapat dihitung atau terbatas. Sementara itu, variabel kontinu adalah variabel dengan nilai tidak terbatas yang dapat diukur atau dicatat sampai tingkat kesempatan yang diperlukan.

Di dalam penelitian data yang akan digunakan dalam pengambilan kesimpulan atau keputusan harus bersifat baik. Ada beberapa syarat data dikatakan baik, yaitu :

1. Obyektif

Artinya data harus sesuai dengan keadaan sebenarnya (as it is), bukan dari hasil imajinasi atau hasil karangan.

2. Representatif

Data harus representatif dimana data harus mewakili permasalahan yang akan dipecahkan.

3. Kesalahan Baku kecil

Suatu perkiraan (estimate) dikatakan baik (memiliki tingkat ketelitian yang tinggi) jika kesalahan bakunya kecil.

4. Tepat Waktu

Data yang akan dikumpulkan harus tepat waktu (up to date), terbaru agar kesimpulan yang dihasilkan sesuai dengan keadaan sekarang.

5. Relevan

Yaitu data yang dikumpulkan harus berhungan dengan masalah yang akan dipecahkan. 
Menurut pembagiannya data dapat dibagi menjadi beberapa jenis diantaranya :

\section{Data menurut Skala Pengukuran}

Dibedakan menjadi empat jenis yaitu :

a. Nominal, sifatnya hanya untuk membedakan antar kelompok.

Contoh : Jenis kelamin (laki-laki, perempuan), Jurusan dalam Fakultas Bisnis, Hukum dan Ilmu Sosial (Manajemen, Akuntansi, Hukum, Ilmu Komunikasi dan Administrasi Publik).

b. Ordinal, selain memiliki sifat nominal, juga menunjukkan peringkat.

Contoh : Tingkat pendidikan (SD, SMP, SMA), Skala perusahaan (besar, sedang, kecil).

c. Interval, selain memiliki sifat data ordinal, juga memiliki sifat interval antar observasi dinyatakan dalam unit pengukuran yang tetap.

Contoh : Temperatur

d. Rasio, selain memiliki sifat data interval, skala rasio memiliki angka 0 (nol) dan perbandingan antara dua nilai mempunyai arti.

Contoh : Tinggi badan, Berat badan, Waktu.

\section{Data menurut Sifatnya}

Dibedakan menjadi dua, yaitu :

a. Kualitatif

Berupa label/nama-nama yang digunakan untuk mengidentifikasikan atribut suatu elemen. Skala pengukuran: Nominal atau Ordinal. Data bisa berupa numeric atau 
nonnumeric. Misalnya, prestasi mahasiswa FBHIS sangat meningkat, kemampuan berpikir kritis mahasiswa FBHIS tinggi, daya beli masyarakat menurun dan sebagainya.

b. Kuantitatif

Mengindikasikan seberapa banyak (how many/diskret atau how much/kontinu). Data selalu numeric. Skala pengukuran: Interval dan Rasio. Misalnya rata-rata nilai Statistika mahasiswa 80, biaya Study Ekskursi kurang lebih Rp 3 juta , 99\% mahasiswa dinyatakan lulus.

\section{Data menurut Sumbernya}

a. Data Internal

yaitu data yang menggambarkan keadaan/kegiatan di dalam suatu organisasi.

Di dalam suatu universitas, misalnya data dosen, data keuangan Fakultas, data mahasiswa, data prestasi mahasiswa, dan sebagainya.

b. Data Eksternal

yaitu data yang menggambarkan keadaan/kegiatan di luar suatu organisasi.

Bagi suatu universitas, misalnya tingkat daya beli masyarakat, tingkat pendapatan penduduk, permintaan (demand), dan sebagainya.

\section{Data menurut Waktu Pengumpulannya}

a. Cross-sectional Data

yaitu data yang dikumpulkan pada waktu tertentu yang sama atau hampir sama. 
Contoh : Jumlah mahasiswa UMSIDA TA 2020/2021, Jumlah perusahaan go public tahun 2020

b. Time Series Data

yaitu data yang dikumpulkan selama kurun waktu/periode tertentu.

Contoh: $\quad$ Pergerakan nilai tukar rupiah dalam 1 bulan, Produksi Padi Indonesia tahun 2019-2020.

\section{Data menurut Cara Memperolehnya}

a. Data Primer

yaitu data yang dikumpulkan dan diolah sendiri oleh suatu organisasi atau perseorangan langsung dari obyeknya. Misalnya, BPS melakukan sensus penduduk tahun 2015 untuk memperoleh data penduduk.

b. Data Sekunder

yaitu data yang diperoleh dalam bentuk yang sudah jadi, sudah dikumpulkan dan diolah oleh pihak lain, biasanya sudah dalam bentuk publikasi. Misalnya, suatu perusahaan memperoleh data penduduk dari BPS, data perbankan dari BI, dan lain sebagainya.

\section{b. Kriteria Keputusan}

Setelah data diolah dengan statistik, kemudian akan menghasilkan berbagai kriteria keputusan. Sama halnya dengan pilihan, masing-masing kriteria keputusan memiliki manfaat dan akibat bagi kita.

\section{c. Keputusan}


Dari beberapa kriteria keputusan kemudian diambil keputusan.

\section{BAB II}

\section{DISTRIBUSI FREKUENSI}

\section{A. PENDAHULUAN}

Distribusi frekuensi adalah data-data yang tersusun menurut kelas-kelas dalam sebuah daftar. Data-data dari hasil penelitian di lapangan yang berupa data acak dan mentah dapat dibuat menjadi data berkelompok berdasarkan kelaskelas tertentu. Ada beberapa unsur-unsur yang terdapat dalam penyusunan tabel distribusi frekuensi diantarany adalah :

1. Class interval (c) atau interval kelas, yaitu sejumlah nilai variabel yang ada dalam batas kelas tertentu, banyaknya kelas bergantung pada banyaknya data. Setiap interval kelas terdiri dari dua batas kelas, yaitu :

a. Batas kelas bawah (BKB) adalah nilai yang membatasi kelas bagian bawah. 
b. Batas kelas atas (BKA) adalah nilai yang membatasi kelas bagian atas.

2. Frekuensi $(f)$ adalah jumlah atau banyaknya data yang diambil dari penelitian.

3. Range $(r)$ adalah rentang nilai antara nilai terbesar dan nilai terkecil data yang diambil dari penelitian.

4. Titik tengah kelas $(M)$ adalah nilai yang terdapat di tengah-tengah interval kelas.

Dimana, $M=\frac{\text { Batas kelas bawah }+ \text { Batas kelas atas }}{2}$

5. Tepi kelas, yaitu batas kelas yang tidak memiliki lubang untuk angka tertentu antara kelas yang satu dengan kelas yang lain. Tepi kelas terdiri dari dua jenis, yaitu :

a. Tepi Kelas Atas, didapatkan dari batas kelas atas ditambah 0,5.

b. Tepi Kelas Bawah, didapatkan dari batas kelas bawah dikurangi 0,5.

6. Frekuensi Kumulatif Kurang Dari (FKDD) adalah frekuensi yang memuat jumlah frekuensi yang memiliki nilai kurang dari nilai batas kelas suatu interval tertentu.

7. Frekuensi Kumulatif Lebih Dari (FKLD) adalah frekuensi yang memuat jumlah frekuensi yang memiliki nilai lebih dari nilai batas kelas suatu interval tertentu.

\section{B. PENYAJIAN MATERI}

1. Tahapan Penyusunan Distribusi Frekuensi 
Didalam menyusun tabel distribusi frekuensi diperlukan langkah-langkah sebagai berikut :

a. Urutkan data dari yang terkecil sampai yang terbesar atau sebaliknya.

b. Tentukan nilai data terkecil, nilai data terbesar, banyak data dan rangenya $(r)$.

c. Menentukan jumlah kelas interval yang diperlukan, atau dengan menggunakan rumus Sturges :

$k=1+3,3 \log n$

Keterangan :

$\mathrm{k}=$ kelas interval

$\mathrm{n}=$ banyaknya data

d. Menentukan panjang kelas interval, yaitu dengan menggunakan rumusan sebagai berikut :

$p=\frac{x_{\text {maks }}-x_{\text {min }}}{k}$

Keterangan :

$\mathrm{p}=$ panjang kelas interval

$\mathrm{x}_{\mathrm{maks}}=$ nilai data terbesar

$x_{\min }=$ nilai data terkecil

e. Melakukan penghitungan, yaitu menghitung dan menentukan batas bawah dan batas atas dari kelas pertama sampai dengan kelas yang terakhir serta melakukan penturusan untuk memasukkan data pada interval kelas yang ada. 


\section{Contoh :}

Di bawah ini adalah data nilai statistik mahasiswa Manajemen kelas 2A1.

$\begin{array}{lllllll}50 & 50 & 95 & 80 & 95 & 70 & 90 \\ 70 & 50 & 95 & 80 & 95 & 70 & 50 \\ 60 & 50 & 50 & 60 & 90 & 90 & 90 \\ 70 & 50 & 60 & 60 & 70 & 70 & 80 \\ 60 & 70 & 70 & 70 & 70 & 50 & 60 \\ 50 & 60 & 60 & 70 & 80 & & \end{array}$

Buatlah tabel distribusi frekuensinya!

Penyelesaian :

Langkah-langkahnya,

a. Mengurutkan data dari yang terkecil,

$\begin{array}{lllllll}50 & 50 & 50 & 50 & 50 & 50 & 50\end{array}$

$\begin{array}{lllllll}50 & 50 & 60 & 60 & 60 & 60 & 60\end{array}$

$\begin{array}{lllllll}60 & 60 & 60 & 70 & 70 & 70 & 70\end{array}$

$\begin{array}{lllllll}70 & 70 & 70 & 70 & 70 & 70 & 70\end{array}$

$\begin{array}{lllllll}80 & 80 & 80 & 80 & 90 & 90 & 90\end{array}$

$\begin{array}{lllll}90 & 95 & 95 & 95 & 95\end{array}$

b. Data terkecil 50, data terbesar 95 dan banyak data 40

Range $(r)=95-40=55$

c. Menentukan jumlah kelas interval, 


$$
\begin{aligned}
k & =1+3,3 \log n \\
& =1+3,3 \log 40 \\
& =1+3,3(1,60206) \\
& =1+5,286798 \\
& =6,286798 \\
& \approx 6(\text { pembulatankebawah }) \\
p & =\frac{x_{\text {maks }}-x_{\text {min }}}{k} \\
& =\frac{95-50}{6} \\
& =\frac{45}{6} \\
& =7,5 \\
& \approx 8(\text { pembulatankeatas })
\end{aligned}
$$

e. Membuat tabel distribusi frekuensi

\begin{tabular}{|c|l|c|}
\hline Interval & \multicolumn{1}{|c|}{ Data } & Frekuensi \\
\hline $50-57$ & $\begin{array}{l}50,50,50,50,50,50, \\
50,50,50\end{array}$ & 9 \\
\hline $58-65$ & $\begin{array}{l}60,60,60,60,60,60, \\
60,60\end{array}$ & 8 \\
\hline $66-73$ & $\begin{array}{l}70,70,70,70,70,70, \\
70,70,70,70,70\end{array}$ & 11 \\
\hline $74-81$ & $\begin{array}{l}80,80,80,80 \\
82-89\end{array}$ & $40,90,90,90$ \\
\hline $90-97$ & $95,95,95,95$ & 4 \\
\hline
\end{tabular}




\section{Histogram, Poligon dan Ogive}

Data yang telah disusun dalam bentuk tabel distribusi frekuensi, selanjutnya dapat dibuat dalam beberapa bentuk diagram, diantaranya

a. Histogram dan Poligon

Histogram adalah diagram batang yang lebarnya menunjukkan interval kelas, sedangkan batas-batas tepi kotak merupakan tepi bawah dan tepi atas kelas, dan tingginya menunjukkan frekuensi pada kelas tersebut. Apabila titik titik tengah sisi atas dari histogram dihubungkan satu sama lain oleh ruas - ruas garis maka diperoleh poligon frekuensi. Untuk lebih memahami mengenai histogram dan poligon frekuensi, perhatikan contoh berikut,

Berikut ini adalah data upah karyawan (dalam ribuan rupiah) per minggu dari sebuah perusahaan.

\begin{tabular}{|c|c|c|c|c|}
\hline Interval & $\begin{array}{c}\text { Tepi } \\
\text { Bawah }\end{array}$ & $\begin{array}{c}\text { Tepi } \\
\text { Atas }\end{array}$ & $\begin{array}{c}\text { Nilai } \\
\text { Tengah }\end{array}$ & Frekuensi \\
\hline $100-199$ & 99,5 & 199,5 & 149,5 & 15 \\
\hline $200-299$ & 199,5 & 299,5 & 249,5 & 20 \\
\hline $300-399$ & 299,5 & 399,5 & 349,5 & 30 \\
\hline $400-499$ & 399,5 & 499,5 & 449,5 & 25 \\
\hline $500-599$ & 499,5 & 599,5 & 549,5 & 15 \\
\hline $600-699$ & 599,5 & 699,5 & 649,5 & 10 \\
\hline $700-799$ & 699,5 & 799,5 & 749,5 & 5 \\
\hline Total & & & & 120 \\
\hline
\end{tabular}


Hasil histogram dan poligon frekuensi dari tabel distribusi frekuensifdi atas dapat dilihat pada gambar berikut,

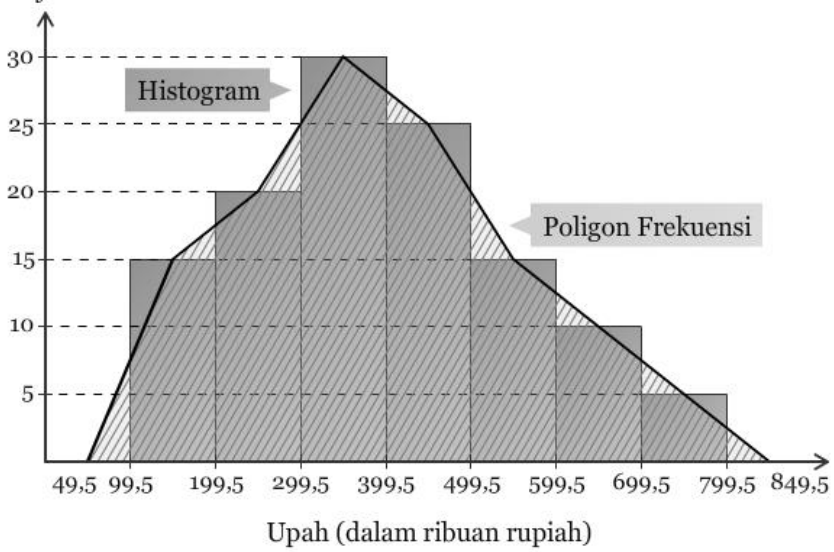

b. Ogive

Ogive adalah grafik yang digambarkan berdasarkan data yang telah disusun dalam bentuk tabel distribusi frekuensi kumulatif. Untuk data yang disusun dalam bentuk tabel distribusi frekuensi kumulatif kurang dari, grafiknya berupa ogive positif, sedangkan untuk data yang disusun dalam bentuk tabel distribusi frekuensi kumulatif lebih dari, grafiknya berupa ogive negatif.

Data upah karyawan pada contoh di atas dapat digambarkan ogivenya. Dengan cara membuat terlebih dahulu tabel distribusi frekuensi kumulatifnya, perhatikan contoh berikut,

\begin{tabular}{|c|c|c|c|}
\hline Interval & Frekuensi & $\begin{array}{c}\text { Frekuensi } \\
\text { Kumulatif } \\
\text { kurang dari }\end{array}$ & $\begin{array}{c}\text { Frekuensi } \\
\text { Kumulatif } \\
\text { lebih dari }\end{array}$ \\
\hline
\end{tabular}




\begin{tabular}{|c|c|c|c|}
\hline $100-199$ & 15 & 15 & 120 \\
\hline $200-299$ & 20 & 35 & 105 \\
\hline $300-399$ & 30 & 65 & 85 \\
\hline $400-499$ & 25 & 90 & 55 \\
\hline $500-599$ & 15 & 105 & 30 \\
\hline $600-699$ & 10 & 115 & 15 \\
\hline $700-799$ & 5 & 120 & 5 \\
\hline Total & 120 & & \\
\hline
\end{tabular}

Dari tabel distribusi frekuensi kumulatif di atas, dapat diperoleh ogive seperti pada gambar berikut,

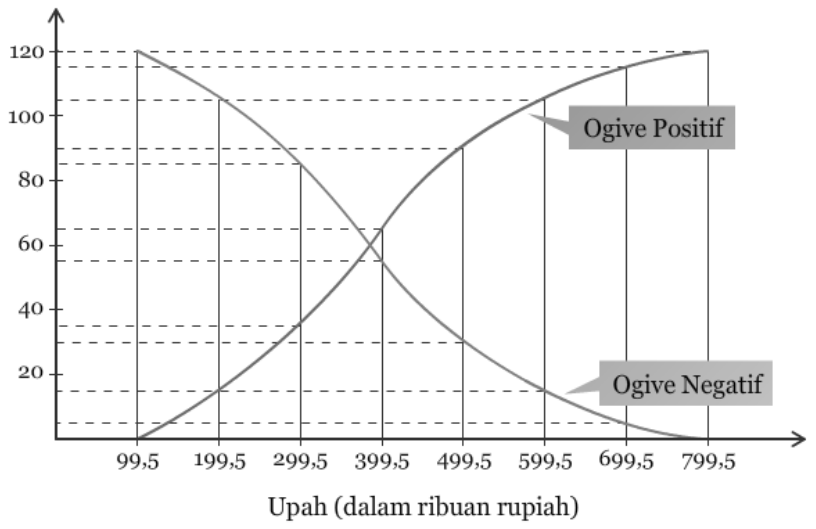

\section{LATIHAN}

Kerjakan soal-soal di bawah ini! 
1. Industri makanan minuman di Sidoarjo meyakini bahwa ada pengaruh antara kenaikan biaya iklan dengan persentase kenaikan penjualan. Oleh sebab itu, dilakukan pendataan terhadap 26 perusahaan makanan minuman untuk melihat kinerja perusahaan ditunjukkan melalui persentase kenaikan penjualan perusahaan sebagai berikut :

$\begin{array}{lllllll}31 & 20 & 39 & 17 & 20 & 11 & 23 \\ 26 & 20 & 47 & 43 & 21 & 10 & 38 \\ 15 & 24 & 49 & 23 & 14 & 51 & 25 \\ 31 & 56 & 37 & 11 & 30 & 27 & 30 \\ 25 & 28 & 31 & 29 & & & \end{array}$

Buatlah :
a. Tabel distribusi frekuensinya!
b. Histogram!
c. Poligon!
d. Ogive!

2. Diketahui nilai Statistik Bisnis dari 70 mahasiswa Manajemen, sebagai berikut :

$\begin{array}{llllllll}70 & 70 & 71 & 60 & 63 & 80 & 81 & 81 \\ & 74 & 66 & 66 & 67 & 67 & 67 & 68 \\ & 76 & 76 & 77 & 77 & 77 & 80 & 80 \\ & 80 & 80 & 73 & 73 & 74 & 74 & 74 \\ & 71 & 72 & 72 & 72 & 72 & 83 & 84 \\ & 84 & 84 & 84 & 75 & 75 & 75 & 75 \\ & 75 & 75 & 75 & 75 & 78 & 78 & 78 \\ 78 & 78 & 79 & 79 & 81 & 82 & 82\end{array}$




$\begin{array}{lllllll}82 & 83 & 89 & 85 & 85 & 87 & 90 \\ 93 & 94 & 94 & 87 & 87 & 89 & \end{array}$

Pertanyaan :

a. Buatlah tabel distribusi frekuensi beserta langkah-langkahnya.

b. Buatlah histogramnya.

c. Buatlah poligonnya.

d. Buatlah ogivenya.

3. Perusahaan dapat diklasifikasikan menurut lapangan usaha. Sebuah sampel yang terdiri dari 20 perusahaan dan diperoleh data sebagai berikut :

\begin{tabular}{|l|l|}
\hline \multicolumn{1}{|c|}{ Nama Perusahaan } & \multicolumn{2}{c|}{ Lapangan Usaha } \\
\hline IBP & Makanan \\
\hline Intel & Elektronik \\
\hline Coca Cola & Minuman \\
\hline Union C & Kimia \\
\hline General Elektrik & Elektronik \\
\hline Motorola & Elektronik \\
\hline Indofood & Makanan \\
\hline Dow Chemical & Kimia \\
\hline Campbell Soup & Makanan \\
\hline R. Purina & Makanan \\
\hline R. Sate & Makanan \\
\hline Mc Donald Douglas & Penerbangan \\
\hline Morton Int & Kimia \\
\hline Indah P & Makanan \\
\hline
\end{tabular}




\begin{tabular}{|l|l|}
\hline Pepsi Co & Minuman \\
\hline Maytag & Elektronik \\
\hline Lockheed & Penerbangan \\
\hline Pet & Makanan \\
\hline Gold Star & Elektronik \\
\hline Samsung Elektronik & Elektronik \\
\hline
\end{tabular}

a. Buatlah distribusi frekuensi yang menunjukkan jumlah perusahaan dalam setiap jenis lapangan usaha.

b. Buatlah distribusi frekuensi relative dari point a. 


\section{BAB III}

\section{STATISTIK DESKRIPTIF}

\section{A. PENDAHULUAN}

Statistik deskriptif adalah pengolahan data statistik yang bertujuan untuk mendeskripsikan atau memberi gambaran terhadap obyek yang diteliti melalui data sampel atau populasi. Data yang diolah dalam statistik deskriptif hanya satuaN variabel saja. Pada statistik deskriptif luaran yang dihasilkan umumnya berupa tabel, grafik dan diagram.

Variabel adalah sesuatu (peubah) yang ditetapkan oleh peneliti untuk dipelajari dengan seksama mengenai karakteristiknya, sehingga diperoleh informasi berupa data dan diolah dengan statistik sehingga dapat disajikan ataupun dapat ditarik kesimpulan.

\section{B. PENYAJIAN MATERI}

Dalam pengujian deskriptif terdapat pengujian nilai ukuran pemusatan data yaitu mean, median dan modus, nilai ukuran letak data yaitu kuartil, dan nilai ukuran penyebaran data yaitu varians, standar deviasi, serta berbagai macam bentuk diagram. 
Berikut ini merupakan ukuran - ukuran untuk melakukan pengujian deskriptif baik untuk data tunggal maupun untuk data berkelompok,

\section{Mean}

Mean atau biasa disebut dengan rata-rata (average) adalah nilai yang mewakili himpunan atau sekelompok data (a set of data), umumnya cenderung terletak di tengah suatu kelompok data yang disusun menurut besar/kecilnya nilai, nilai rata-rata kecenderungan memusat (measures of central tendency).

Beberapa jenis rata-rata yang sering dipergunakan adalah rata-rata hitung (arithmetic mean atau disebut mean), ratarata ukur (geometric mean), dan rata-rata harmonis (harmonic mean), setiap rata-rata memiliki keunggulan dan kekurangan, ketepatan penggunaan nya sangat tergantung pada sifat dari data dan tujuannya (misal, untuk melakukan analisa).

Yang akan kita bahas adalah rata-rata hitung, contohnya ratarata gaji/upah karyawan perusahaan swasta per bulan. Ratarata nilai hasil ujian seorang mahasiswa, rata-rata jarak yang ditempuh oleh pembalap mobil, dan lain sebagainya.

\section{Rumus untuk Data Tunggal} $\bar{x}=\frac{x_{1}+x_{2}+x_{3}+\ldots+x_{n}}{n}$

Keterangan : 


$$
\begin{aligned}
& \bar{x}=\text { mean } \\
& x_{1}=\text { nilai data pertama } \\
& x_{2}=\text { nilai data kedua } \\
& x_{n}=\text { nilai data ke }-n \\
& n=\text { jumlahsampelatau banyakdata }
\end{aligned}
$$

\section{Rumus untuk Data Berkelompok}

$$
\bar{x}=\frac{\sum f_{i} \cdot M_{i}}{\sum f_{i}}
$$

Keterangan :

$$
\bar{x} \quad=\text { mean }
$$

$M_{i} \quad=$ nilaitengah $\mathrm{ke}-i$

$\sum f_{i} \quad=$ jumlahdata $/$ sampel

$$
\begin{aligned}
\sum f_{i} \cdot M_{i}= & \text { jumlahperkalianantarafrekuensidengan } \\
& \text { nilai tengah }-i
\end{aligned}
$$

\section{Median}

Median adalah nilai yang terletak di tengah suatu kumpulan data, dengan jalan membagi data menjadi dua bagian sama besar dan kemudian menghitung nilai data yang membagi menjadi dua bagian sama besar tersebut. Selanjutnya disingkat sebagai Med. Untuk mencari median dari data tunggal, data yang ada harus diurutkan terlebih dahulu, kemudian dicari dengan menggunakan :

\section{Rumus untuk Data Tunggal}


Med $=x_{\frac{n+1}{2}}$

Keterangan :

Med $=$ nilai median

$n \quad$ = jumlah sampel/banyaknya data.

\section{Rumus untuk Data Kelompok}

Menentukan kelas median dengan menggunakan

$$
\left.\frac{1}{2} \times n\right)
$$

Keterangan :

Med = nilai median

$T_{b} \quad=$ tepibawahkelas median

$p \quad=$ panjangkelasinterval

$n$ = banyakdata/ jumlahsampel

$F K_{s}=$ frekuensikumulatif sebelumkelasmedian

$f_{m}=$ frekuensikelas median

\section{Modus}

Modus dari suatu kelompok nilai adalah nilai kelompok tersebut yang mempunyai frekuensi tertinggi atau nilai yang paling banyak terjadi di dalam suatu kelompok nilai, selanjutnya kita singkat Mod. 
Oleh karena itu, dalam kumpulan data mungkin saja tidak memiliki modus, kumpulan data disebut Unimodal (jika mempunyai satu modus), Bimodal (jika mempunyai dua modus) dan Multimodal (jika mempunyai lebih dari dua modus)

Di dalam bidang pemasaran, ukuran modus ini juga sering dipergunakan untuk mengetahui barang apa yang paling disenangi para konsumen, atau dengan perkataan lain apa yang menjadi mode. Misal : Mode pakaian, mode sepatu, potongan rambut yang paling disenangi, jenis film yang paling banyak pengunjungnya, fakultas yang paling banyak mahasiswanya dan sebagainya.

\section{Rumus untuk Data Tunggal}

$M o d=$ dicari data yang paling sering muncul

\section{Rumus untuk Data Berkelompok}

Menentukan kelas modus dengan memilih kelas interval dengan frekuensi terbesar.

$\operatorname{Mod}=\mathrm{T}_{\mathrm{b}}+p\left(\frac{b_{1}}{b_{1}+b_{2}}\right)$

Keterangan :

Mod = nilai modus

$T_{b} \quad=$ tepi bawah kelas modus

$p \quad=$ panjang interval kelas

$b_{1}=$ selisih frekuensi kelas modus dengan frekuensi

kelas sebelumnya

$b_{2}=$ selisih frekuensi kelas modus dengan frekuensi 


\section{kelas sesudahnya}

\section{Kuartil}

Kuartil adalah suatu nilai yang didapatkan dengan jalan membagi kumpulan data menjadi empat bagian yang sama besar. Besarnya data adalah jumlah data, sehingga jika ada 10 data maka kuartil membagi setiap 10/4 atau 2,5 data, maka kuartil dapat mengetahui besar data setiap 2,5 buah data.

Dengan demikian, pada saat setiap data berapapun jumlahnya, jika akan dibagi menjadi kuartil akan selalu ada tiga buah kuartil, yaitu kuartil $1\left(Q_{1}\right)$, kuartil $2\left(Q_{2}\right)$ dan kuartil 3 $\left(Q_{3}\right)$.

\section{Rumus untuk Data Tunggal}

$\mathrm{Q}_{\mathrm{i}}=\frac{x_{i(n+1)}}{4}$

Keterangan :

$Q_{\mathrm{i}}=$ kuartil ke-i

$I=1,2,3$

$n=$ jumlah sampel / banyak data

\section{Rumus untuk Data Berkelompok}

Menentukan kelas kuartil dimana $Q_{i}$ berada

$$
\frac{\mathrm{i}}{4} \times n
$$

Dimana $i=1,2,3$

$$
\mathrm{Q}_{\mathrm{i}}=T_{b}+p\left(\frac{\frac{i n}{4}-F K_{s}}{f Q_{i}}\right)
$$


Keterangan :

$\mathrm{Q}_{\mathrm{i}} \quad=$ nilaikuartilke- $\mathrm{i}$

$T_{b} \quad=$ tepibawahkelas median

$p \quad=$ panjangkelasinterval

$\mathrm{i}=1,2,3$

$n \quad=$ banyakdata / jumlahsampel

$F K_{s}=$ frekuensikumulatif sebelumkelaskuartil ke -i

$f Q_{i}=$ frekuensikelaskuartil ke-i

\section{Varians}

Varians adalah data yang menggambarkan bagaimana suatu kelompok data menyebar terhadap pusat data atau ukuran penyebaran suatu kelompok data terhadap pusat data, atau dengan kata lain data yang menggambarkan bias data dari rata-rata sampelnya.

\section{Rumus untuk Data Tunggal}

$$
\sigma^{2}=\frac{\left(x_{1}-\bar{x}\right)^{2}+\left(x_{2}-\bar{x}\right)^{2}+\ldots\left(x_{n}-\bar{x}\right)^{2}}{n-1}
$$

Keterangan :

$\sigma^{2}=$ varians

$x_{1}=$ data pertama

$x_{2}=$ data kedua

$\bar{x}=$ rata - rata nilaidata

$n$ = jumlahsampel/banyakdata 


\section{Rumus untuk Data Berkelompok}

$\sigma^{2}=\frac{\sum f_{i}\left(M_{i}-\bar{x}\right)^{2}}{n-1}$

Keterangan :

$\sigma^{2}=$ varians

$f_{i}=$ frekuensike $-\mathrm{i}$

$M_{i}=$ nilaitengahimtervalke $-\mathrm{i}$

$\bar{x}=$ rata - rata nilai data

$n$ = jumlahsampel/banyakdata

\section{Standar Deviasi}

Standar Deviasi adalah akar dari varians yang menunjukkan simpangan setiap pengamatan terhadap rata-rata hitungnya, dikenal juga sebagai simpangan baku.

Rumus untuk Data Tunggal

$\sigma=\sqrt{\frac{\left(x_{1}-\bar{x}\right)^{2}+\left(x_{2}-\bar{x}\right)^{2}+\ldots\left(x_{n}-\bar{x}\right)^{2}}{n-1}}$

Atau $\sigma=\sqrt{\text { varians }}$

Keterangan :

$\sigma=$ standardeviasi

$x_{1}=$ data pertama

$x_{2}=$ data kedua

$\bar{x}=$ rata - rata nilai data

$n$ = jumlah sampel/banyakdata 


\section{Rumus untuk Data Berkelompok}

$\sigma=\sqrt{\frac{\sum f_{i}\left(M_{i}-\bar{x}\right)^{2}}{n-1}}$

Atau $\sigma=\sqrt{\text { varians }}$

Keterangan :

$\sigma=$ standardeviasi

$f_{i}=$ frekuensike $-\mathrm{i}$

$M_{i}=$ nilai tengahimtervalke $-\mathrm{i}$

$\bar{x}=$ rata - rata nilai data

$n$ = jumlahsampel/banyakdata

\section{Diagram Lingkaran}

Diagram lingkaran (pie chart) adalah diagram berbentuk lingkaran yang dibagi berdasarkan kategori dengan persentasenya. Diagram lingkaran dapat digunakan untuk skala interval dan rasio.

Contohnya sebagai berikut :

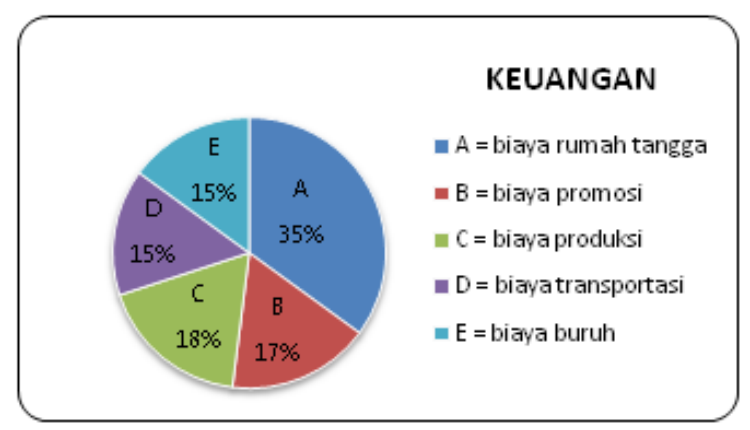




\section{Contoh Soal :}

1. Untuk data tunggal

Di bawah ini adalah data nilai statistik mahasiswa manajemen dengan jumlah 10 orang.

\begin{tabular}{|c|c|c|}
\hline No & Nama & Nilai Statistik \\
\hline 1. & Wildan & 50 \\
\hline 2. & Vivi & 50 \\
\hline 3. & Jeje & 100 \\
\hline 4. & Rizal & 80 \\
\hline 5. & Aisyah & 95 \\
\hline 6. & Nissa & 70 \\
\hline 7. & Didin & 90 \\
\hline 8. & Adisti & 60 \\
\hline 9. & Rafi & 70 \\
\hline 10. & Yusuf & 50 \\
\hline
\end{tabular}

Dari data di atas hitunglah :
a. Mean
b. Median
c. Modus
d. Kuartil
e. Varians
f. Standar deviasi
g. Diagram Lingkaran

Penyelesaian :
a. Mean 


$$
\begin{aligned}
\bar{x} & =\frac{50+50+100+80+95+70+90+60+70+50}{10} \\
& =\frac{715}{10} \\
& =71,5 \\
& \text { b. Median }
\end{aligned}
$$

Data diurutkan terlebih dahulu, 50, 50, 50, 60, 70, 70, 80, 90, 95, 100

$$
\begin{aligned}
\text { Med } & =x_{\frac{n+1}{2}} \\
& =x_{\frac{10+1}{2}} \\
& =x_{\frac{11}{2}} \\
& =x_{5,5}
\end{aligned}
$$

Jadi posisi median berada pada data ke- 5,5 yaitu 70,70

Sehingga nilai mediannya $=\frac{70+70}{2}=70$

c. Modus

Dengan mengamati nilai yang paling sering muncul.

Mod $=50$ (karena nilai 50 muncul paling tiga kali)

\section{d. Kuartil}

Data diurutkan terlebih dahulu, $50,50,50,60,70,70,80,90,95,100$

Maka didapatkan, $Q_{1}=50, Q_{2}=70$ dan $Q_{3}=90$ 

e. Varians

Mencari rata-rata hitung terlebih dahulu,

$$
\begin{aligned}
\bar{x} & =\frac{50+50+100+80+95+70+90+60+70+50}{10} \\
& =\frac{715}{10} \\
& =71,5
\end{aligned}
$$

\begin{tabular}{|c|c|c|c|}
\hline Data ke- & Nilai $\left(x_{\mathrm{i}}\right)$ & $\left(x_{\mathrm{i}}-\bar{x}\right)$ & $\left(x_{\mathrm{i}}-\bar{x}\right)^{2}$ \\
\hline 1 & 50 & $-21,5$ & 462,25 \\
\hline 2 & 50 & $-21,5$ & 462,25 \\
\hline 3 & 50 & $-21,5$ & 462,25 \\
\hline 4 & 60 & $-11,5$ & 132,25 \\
\hline 5 & 70 & 1,5 & 2,25 \\
\hline 6 & 70 & 1,5 & 2,25 \\
\hline 7 & 80 & 8,5 & 72,25 \\
\hline 8 & 90 & 18,5 & 342,25 \\
\hline 9 & 95 & 23,5 & 552,25 \\
\hline 10 & 100 & 28,5 & 812,25 \\
\hline Total & & & $3.302,5$ \\
\hline
\end{tabular}

Maka $\sigma^{2}=\frac{3.302,5}{9}=366,94$

Semakin besar varians sebuah data maka semakin menyebar / bervariasi data tersebut, demikian juga sebaliknya.

f. Standar deviasi

Maka didapatkan standar deviasi, 


$$
\sigma=\sqrt{\sigma^{2}}=\sqrt{366,94}=19,156
$$

g. Diagram Lingkaran

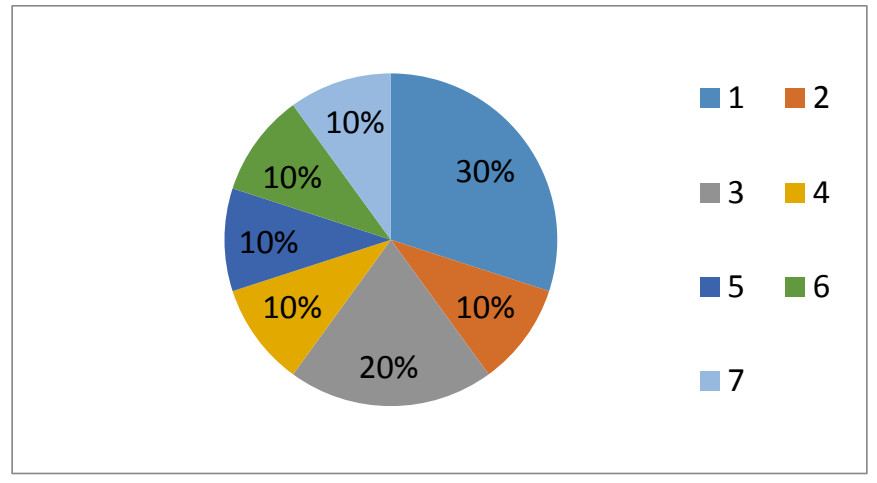

2. Untuk data berkelompok

Di bawah ini merupakan data nilai statistik dari 40 mahasiswa manajemen,

\begin{tabular}{|c|c|}
\hline Interval & Frekuensi \\
\hline $50-57$ & 9 \\
\hline $58-65$ & 8 \\
\hline $66-73$ & 11 \\
\hline $74-81$ & 4 \\
\hline $82-89$ & 4 \\
\hline $90-97$ & 4 \\
\hline Total & 40 \\
\hline
\end{tabular}

Dari data di atas hitunglah :
a. Mean
b. Median
c. Modus 

d. Kuartil
e. Varians
f. Standar deviasi

Penyelesaian :

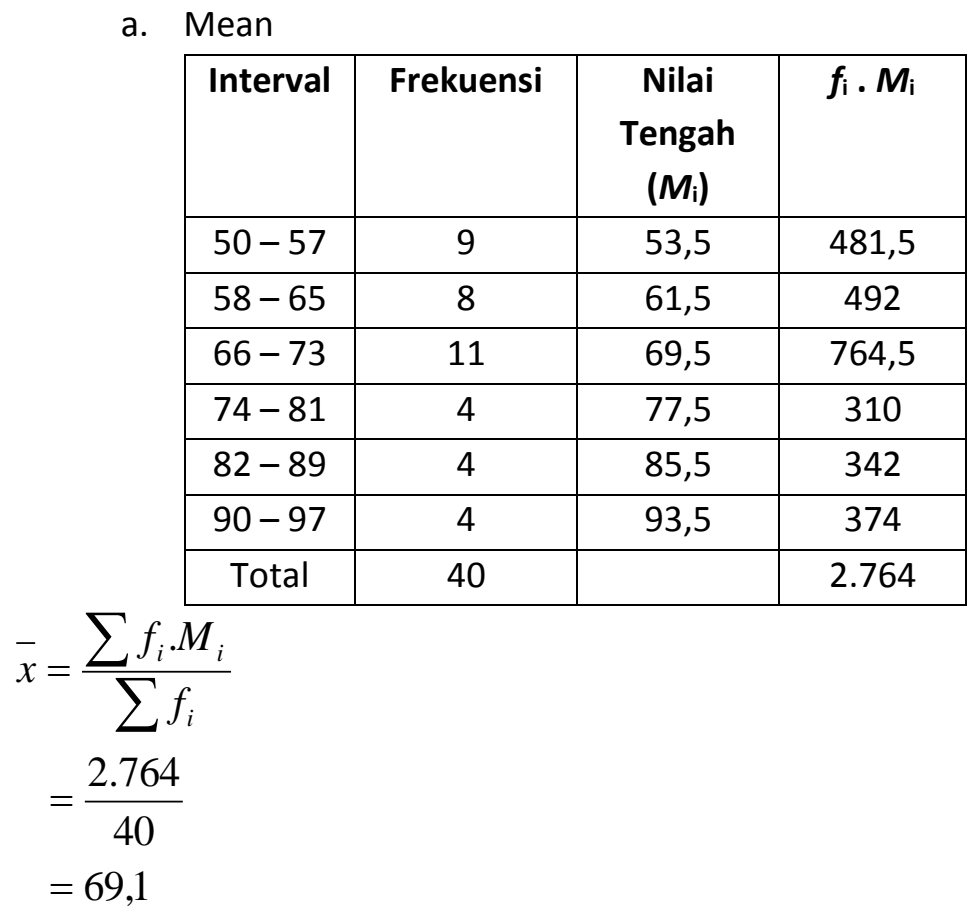

b. Median

\begin{tabular}{|c|c|c|}
\hline Interval & Frekuensi & $\begin{array}{c}\text { Frekuensi Kumulatif } \\
\text { (FK) }\end{array}$ \\
\hline $50-57$ & 9 & 9 \\
\hline $58-65$ & 8 & 17 \\
\hline
\end{tabular}




\begin{tabular}{|c|c|c|}
\hline $66-73$ & 11 & 28 \\
\hline $74-81$ & 4 & 32 \\
\hline $82-89$ & 4 & 36 \\
\hline $90-97$ & 4 & 40 \\
\hline Total & 40 & \\
\hline
\end{tabular}

Menentukan kelas median dengan menggunakan

$$
\frac{1}{2} \times n=\frac{1}{2} \times 40=20
$$

Didapatkan kelas median terletak pada kelas interval ke-3 yaitu pada saat frekuensi kumulatif mencapai 28.

Sehingga,

$$
\begin{aligned}
& \begin{array}{l}
T_{b}=65,5 \\
p=8
\end{array} \\
& F K_{s}=17 \\
& f_{m}=11 \\
& \begin{aligned}
\text { Med } & =T_{b}+p\left(\frac{\frac{1}{2} n-F K_{s}}{f_{m}}\right) \\
& =65,5+8\left(\frac{20-17}{11}\right) \\
& =65,5+8\left(\frac{3}{11}\right) \\
& =65,5+2,18 \\
& =67,68
\end{aligned}
\end{aligned}
$$

c. Modus 
Menentukan kelas modus dengan memilih kelas interval dengan frekuensi terbesar, dan didapatkan kelas interval ke-3 sebagai kelas modus.

Sehingga,

$$
\begin{aligned}
& T_{b}=65,5 \\
& p=8 \\
& b_{1}=11-8=3 \\
& b_{2}=11-4=7 \\
& \operatorname{Mod}=\mathrm{T}_{\mathrm{b}}+p\left(\frac{b_{1}}{b_{1}+b_{2}}\right) \\
& \quad=65,5+8\left(\frac{3}{3+7}\right) \\
& \quad=65,5+8\left(\frac{3}{10}\right) \\
& =65,5+2,4 \\
& =67,9
\end{aligned}
$$

d. Kuartil

\begin{tabular}{|c|c|c|}
\hline Interval & Frekuensi & $\begin{array}{c}\text { Frekuensi Kumulatif } \\
\text { (FK) }\end{array}$ \\
\hline $50-57$ & 9 & 9 \\
\hline $58-65$ & 8 & 17 \\
\hline $66-73$ & 11 & 28 \\
\hline $74-81$ & 4 & 32 \\
\hline $82-89$ & 4 & 36 \\
\hline $90-97$ & 4 & 40 \\
\hline
\end{tabular}




\begin{tabular}{|l|l|l|}
\hline Total & 40 & \\
\hline
\end{tabular}

1. Menentukan Kuartil 1

Kuartil 1 berada pada kelas interval,

$$
\frac{1}{4} \times n=\frac{1}{4} \times 40=10
$$

Didapatkan kelas kuartil 1 terletak pada kelas interval ke-2 yaitu pada saat frekuensi kumulatif mencapai 17.

Sehingga,

$$
\begin{aligned}
& T_{b}=57,5 \\
& p=8 \\
& F K_{s}=9 \\
& f Q_{1}=8 \\
& \mathrm{Q}_{1}=T_{b}+p\left(\frac{\frac{n}{4}-F K_{s}}{f Q_{1}}\right) \\
& \quad=57,5+8\left(\frac{10-9}{8}\right) \\
& \quad=57,5+8\left(\frac{1}{8}\right) \\
& \quad=57,5+1 \\
& \quad=58,5
\end{aligned}
$$

2. Menentukan Kuartil 2

Kuartil 2 berada pada kelas interval,

$$
\frac{2}{4} \times n=\frac{2}{4} \times 40=20
$$


Didapatkan kelas kuartil 2 terletak pada kelas interval ke-3 yaitu pada saat frekuensi kumulatif mencapai 28.

Sehingga,

$$
\begin{aligned}
& T_{b}=65,5 \\
& p=8 \\
& F K_{s}=17 \\
& f Q_{2}=11 \\
& \mathrm{Q}_{2}=T_{b}+p\left(\frac{\frac{2 n}{4}-F K_{s}}{f Q_{2}}\right) \\
& \quad=65,5+8\left(\frac{20-17}{11}\right) \\
& \quad=57,5+8\left(\frac{3}{11}\right) \\
& \quad=57,5+2,18 \\
& \quad=58,68
\end{aligned}
$$

3. Menentukan Kuartil 3

Kuartil 3 berada pada kelas interval,

$$
\frac{3}{4} \times n=\frac{3}{4} \times 40=30
$$

Didapatkan kelas kuartil 2 terletak pada kelas interval ke-4 yaitu pada saat frekuensi kumulatif mencapai 32.

Sehingga, 


$$
\begin{aligned}
T_{b} & =73,5 \\
p & =8 \\
F K_{s} & =28 \\
f Q_{3} & =4 \\
Q_{3} & =T_{b}+p\left(\frac{\frac{3 n}{4}-F K_{s}}{f Q_{3}}\right) \\
& =73,5+8\left(\frac{30-28}{4}\right) \\
& =73,5+8\left(\frac{2}{4}\right) \\
& =73,5+4 \\
& =77,5
\end{aligned}
$$

e. Varians

Dimana telah didapatkan $\bar{x}=69,1$

\begin{tabular}{|c|c|c|l|l|l|}
\hline Interval & $f_{\mathrm{i}}$ & $\boldsymbol{M}_{\mathrm{i}}$ & $\left(M_{\mathrm{i}}-\bar{x}\right)$ & $\left(M_{\mathrm{i}}-\bar{x}\right)^{2}$ & $f_{\mathrm{i}}\left(M_{\mathrm{i}}-\bar{x}\right)^{2}$ \\
\hline $50-57$ & 9 & 53,5 & $-15,6$ & 243,36 & 2190,24 \\
\hline $58-65$ & 8 & 61,5 & $-7,6$ & 57,76 & 462,08 \\
\hline $66-73$ & 11 & 69,5 & 0,4 & 0,16 & 1,76 \\
\hline $74-81$ & 4 & 77,5 & 8,4 & 70,56 & 282,24 \\
\hline $82-89$ & 4 & 85,5 & 16,4 & 268,96 & 1075,84 \\
\hline $90-97$ & 4 & 93,5 & 24,4 & 595,36 & 2381,44 \\
\hline Total & 40 & & & & 6393,60 \\
\hline
\end{tabular}

Sehingga, 


$$
\begin{aligned}
\sigma^{2} & =\frac{\sum f_{i}\left(M_{i}-\bar{x}\right)^{2}}{n-1} \\
& =\frac{6.393,60}{39} \\
& =163,94
\end{aligned}
$$

f. Standar deviasi

Maka didapatkan standar deviasi,

$$
\sigma=\sqrt{\sigma^{2}}=\sqrt{163,94}=12,8
$$

\section{LATIHAN}

Kerjakan Soal-soal di Bawah ini!

1. Besarnya pembayaran rekening listrik bulan lalu dari 21 pelanggan rumah tangga dalam rupiah adalah sebagai berikut :

$\begin{array}{lllllll}5400 & 4800 & 5800 & 5000 & 2500 & 4700 & 7500 \\ 4600 & 6000 & 7000 & 6700 & 6800 & 3900 & 3500 \\ 5600 & 6600 & 3300 & 6200 & 6500 & 6700 & 5000 \\ \text { Hitunglah : } & & & & & \end{array}$
a. Mean
b. Median
c. Modus
d. Kuartil
e. Varians
f. Standar deviasi 
2. Berikut adalah data konsumsi beras selama satu bulan dari 74 rumah tangga,

\begin{tabular}{|c|c|}
\hline Konsumsi beras (kg) & Banyaknya keluarga \\
\hline $5-24$ & 2 \\
\hline $25-44$ & 7 \\
\hline $45-64$ & 5 \\
\hline $65-84$ & 14 \\
\hline $85-104$ & 22 \\
\hline $105-124$ & 14 \\
\hline $125-144$ & 6 \\
\hline $145-164$ & 4 \\
\hline
\end{tabular}

Hitunglah :
a. Mean
b. Median
c. Modus
d. Kuartil
e. Varians
f. Standar Deviasi 


\section{BAB IV}

\section{PROBABILITAS}

\section{A. PENDAHULUAN}

Dalam kehidupan sehari-hari seringkali kita dihadapkan pada beberapa pilihan yang harus diambil menjadi keputusan dan sebisa mungkin pilihan yang kita ambil tersebut merupakan keputusan yang tepat. Misalkan, ketika sebuah perusahaan akan mengeluarkan dua produk terbarunya dengan keunggulan yang berbeda (misalkan yang satu pada segi rasa dan yang satunya pada segi tampilan) maka perusahaan tersebut akan dihadapkan pada dua permasalahan yaitu kemungkinan produk tersebut diterima oleh pasar atau tidak 
diterima oleh pasar. Dan untuk membantu memecahkan permasalahan tersebut salah satunya adalah materi tentang peluang (probabilitas).

\section{B. PENYAJIAN MATERI}

\section{Pengertian Probabilitas}

Peluang atau Probabilitas adalah suatu ukuran dimana suatu kemungkinan akan terjadi di masa mendatang dengan menggunakan peramalan statistik. Probabilitas juga dapat diartikan sebagai besaran angka yang menunjukkan kemungkinan suatu peristiwa terjadi diantara beberapa peristiwa yang akan mungkin terjadi.

Simbol dari probabilitas adalah $P(A)$ yaitu besarnya kemungkinan terjadinya peristiwa $A$. Probabilitas dinyatakan dalam bentuk angka mulai 0 sampai dengan $1(0 \leq P(A) \leq 1)$ atau dalam bentuk \%. Semakin besar kemungkinan terjadinya suatu peristiwa maka nilai probabilitasnya mendekati 1 , demikian juga sebaliknya, semakin kecil kemungkinan terjadinya suatu peristiwa maka nilai probabilitasnya mendekati 0.

\section{Manfaat Probabilitas dalam Penelitian}

Peluang atau Probabilitas mempunyai manfaat untuk membantu dalam pengambilan keputusan yang tepat, karena pada hakikatnya kehidupan yang ada di dunia ini mengandung ketidakpastian dan informasi yang ada penuh dengan ketidaksempurnaan, demikian juga halnya yang terjadi pada kegiatan bisnis.

Contoh : 
1. Sebuah perusahaan yang akan meluncurkan produk baru, maka tim analisis marketing akan dihadapkan pada kemungkinan produk yang akan diluncurkan tersebut akan diterima oleh pasar atau tidak.

2. Ketika pada kegiatan perdagangan saham, pembeli akan dihadapkan pada pilihan jual atau beli saham perusahaan untuk mendapatkan keuntungan ataupun kerugian.

Dalam kehidupan sehari-hari manfaat probabilitas dapat ditemukan seperti pada contoh berikut :

1. Dalam dunia bisnis, probabilitas seringkali digunakan dalam pengambilan keputusan. Misalkan, penentuan kapasitas produksi dalam satu bulan yang didasarkan pada data penjualan produk di masa sebelumnya sehingga dapat menentukan kapasitas produksi untuk produk ini di masa mendatang.

2. Dalam dunia perdagangan saham, para pemain saham dan investor seringkali menggunakan probabilitas untuk dapat memperoleh keuntungan semaksimal mungkin dengan menanamkan saham pada perusahaan tertentu.

\section{Pendekatan Probabilitas}

Ada tiga pendekatan konsep dalam menentukan nilai probabilitas dari suatu kejadian, yaitu :

1. Pendekatan Klasik 
Pendekatan klasik adalah pendekatan dimana akan diperoleh suatu peluang yang kemungkinan akan muncul dari beberapa pilihan yang diajukan. Probabilitas ini dinyatakan dalam perbandingan antara jumlah kemungkinan hasil dengan total kemungkinan hasil (perbandingan jumlah peristiwa dengan jumlah hasil) Probabilitas $=\frac{\text { Jumlah kemungkinan hasil }}{\text { Jumlah total kemungkinan hasil }}$

\section{Contoh 1}

Terdapat 20 supplier alat kesehatan di masa covid 19 ini yang terdiri dari 6 perusahaan swasta luar negeri (A) dan 14 perusahaan swasta dalam negeri (B). Jika akan dipilih 1 supplier tetap untuk sebuah alat kesehatan tertentu maka berapa peluang bahwa ia merupakan perusahaan swasta dalam negeri?

\section{Penyelesaian :}

$\mathrm{n}(A)=6$

$\mathrm{n}(B)=14$

$\mathrm{n}(S)=20$

maka,

$$
\begin{aligned}
\mathrm{P}(\mathrm{B}) & =\frac{\mathrm{n}(\mathrm{B})}{\mathrm{n}(\mathrm{S})} \\
& =\frac{14}{20} \\
& =0,70 \text { atau } 70 \%
\end{aligned}
$$

Peluang perusahaan swasta dalam negeri menjadi supplier tetap adalah $70 \%$. 


\section{Contoh 2}

Sebuah pabrik lampu memproduksi 100 buah lampu LED, setelah diperiksa ternyata ditemukan terdapat 15 buah lampu LED yang cacat, tentukan peluang pembeli membeli satu produk secara acak dan mendapatkan produk yang tidak cacat?

\section{Penyelesaian :}

$\mathrm{n}(\mathrm{S})=100$

$\mathrm{n}(C)=15$

$\mathrm{n}\left(C^{\prime}\right)=100-15=85$

maka

$$
\begin{aligned}
P\left(C^{\prime}\right) & =\frac{n\left(C^{\prime}\right)}{n(S)} \\
& =\frac{85}{100} \\
& =0,85 \text { atau } 85 \%
\end{aligned}
$$

Peluang / Probabilitas pembeli membeli produk tidak cacat adalah $85 \%$

\section{Pendekatan Relatif}

Pendekatan relatif adalah pendekatan dimana besarnya probabilitas suatu peristiwa tergantung pada banyaknya peristiwa yang terjadi dari keseluruhan percobaan atau kegiatan yang dilakukan, probabilitasnya dinyatakan dalam bentuk sebagai berikut : Probabilitas $=\frac{\text { Jumlah peristiwa yang terjadi di masa lalu }}{\text { Jumlah total percobaanatau kegiatan }}$ 


\section{Contoh 1}

Dari hasil survey lapangan diketahui bahwa akan ada 7 perusahaan pernenang tender untuk pemeliharaan fasilitas umum. Tentukan probabilitas terjadi 1 perusahaan yang akan menang dari 200 peserta tender yang ikut serta?

\section{Penyelesaian :}

$$
\mathrm{P}(\mathrm{A})=\frac{7}{200}=0,035
$$

\section{Contoh 2}

Dari hasil tracer study didapatkan bahwa lulusan mahasiswa Manajemen di sebuah Umsida tahun 2018 sebanyak 500 mahasiswa, terdapat 425 mahasiswa bekerja sesuai dengan bidangnya, dan sisanya yaitu 75 mahasiswa bekerja tidak sesuai dengan bidangnya. Berapa probabilitas peristiwa yang akan terjadi pada rnahasiswa yang bekerja tidak sesuai bidangnya?

\section{Penyelesaian :}

$$
\mathrm{P}(\mathrm{A})=\frac{15}{500}=0,03
$$

\section{Pendekatan Subyektif}

Pendekatan subyektif adalah pendekatan dimana besarnya suatu probabilitas atau peluang didapatkan berdasarkan penilaian seseorang, besamya probabilitas yang diperkirakan oleh seseorang itu berasal dari pengalaman yang telah didapatkannya dan berdasarkan beberapa informasi yang tersedia. Sehingga jika tidak mernpunyai pengalarnan dan informasi yang cukup maka sifat dugaannya ada subyektif. 


\section{Contoh 1}

Menduga kemungkinan mahasiswa A mendapatkan nilai $\mathrm{A}$

\section{Contoh 2}

Menduga juara Piala Dunia tahun 2022

\section{Aturan-aturan dalam Probabilitas}

Dalam ilmu probabilitas terdapat beberapa peristiwaperistiwa yang mungkin terjadi, peristiwa tersebut antara lain adalah:

1. Peristiwa bersifat bersifat lepas (mutually exclusive).

Yaitu peristiwa dimana satu peristiwa tidak diikuti peristiwa lain yang terjadi pada saat yang sama, rnisalnya suatu saham yang dibeli tidak mungkin untung dan rugi pada saat yang bersarnaan, pasti

kemungkinan yang terjadi adalah salah satunya, untung saja atau rugi saja.

Aturan penjumlahannya dirumuskan dengan,

$\mathrm{P}($ Aatau $B)=P(A)+P(B)$

Atau

$\mathrm{P}(\mathrm{A} \cup B)=P(A)+P(B)$

Digambarkan dalam diagram venn berikut,

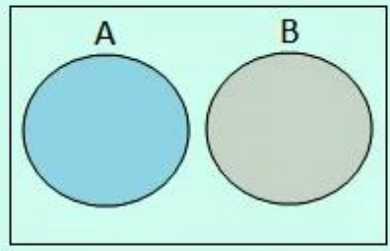

A dan B saling lepas 


\section{Contoh}

Pada kegiatan perdagangan saham di bursa efek untuk 4 perusahaan makanan dan minuman terjadi sebanyak 500 transaksi sebagai berikut :

\begin{tabular}{|c|c|}
\hline Jenis Transaksi & Volume Transaksi \\
\hline Jual saham & 320 \\
\hline Beli saham & 180 \\
\hline Total & 500 \\
\hline
\end{tabular}

Berapakah probabilitas jual atau beli saham pada kegiatan perdagangan di atas?

\section{Penyelesaian :}

Probabilitas jual saham $\mathrm{P}(\mathrm{A})=\frac{320}{500}=0,64$

Probabilitas beli saham $\mathrm{P}(\mathrm{B})=\frac{180}{500}=0,36$

Dengan menggunakan rumusan peluang kejadian saling lepas, maka probabilitas jual atau beli saham adalah $\mathrm{P}(\mathrm{A} \cup \mathrm{B})=P(A)+P(B)=0,64+0,36=1$

Apabila dirinci kegiatan perdagangan saham dari 4 perusahaan makanan dan minuman yaitu sebagai berikut,

\begin{tabular}{|l|c|}
\hline \multicolumn{1}{|c|}{ Perusahaan } & Volume Transaksi \\
\hline Indofood Sukses Makmur & 115 \\
\hline Mayora Indah & 110 \\
\hline Siantar Top & 105 \\
\hline Sekar Laut & 170 \\
\hline Total Transaksi & $\mathbf{5 0 0}$ \\
\hline
\end{tabular}


Probabilitas Indofood Sukses Makmur P(A) $=\frac{115}{500}=0,23$

Probabilitas Mayora Indah $\mathrm{P}(\mathrm{B})=\frac{110}{500}=0,22$

Probabilitas Siantar Top $\mathrm{P}(\mathrm{C})=\frac{105}{500}=0,21$

Probabilitas Sekar Laut P(D) $=\frac{170}{500}=0,34$

- Probabilitas Indofood Sukses Makmur atau Mayora Indah $\mathrm{P}(\mathrm{A} \cup \mathrm{B})=0,23+0,22=0,45$

- Probabilitas Siantar Top atau Sekar Laut $\mathrm{P}(\mathrm{C} \cup \mathrm{D})=0,21+0,34=0,55$

2. Peristiwa Bersama

Yaitu peristiwa dimana terdapat 2 peristiwa atau lebih terjadi pada waktu yang bersamaan, dikenal sebagai kejadian tidak saling lepas.

Aturan penjumlahan yang digunakan untuk menggabungkan peristiwa yang tidak saling lepas adalah sebagai berikut, $\mathrm{P}(\mathrm{A}$ atau $B)=P(A)+P(B)-P(A$ dan $B)$

Atau

$\mathrm{P}(\mathrm{A} \cup B)=P(A)+P(B)-P(A \cap B)$

Digambarkan dalam diagram venn berikut,

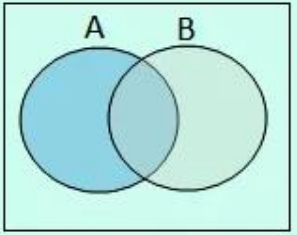

A dan B tidak saling lepas 


\section{Contoh 1}

Dari hasil survei terhadap 1000 mahasiswa FBHIS, yang mengikuti ujian mata kuliah Matematika Bisnis dan atau Statistika Bisnis, diperoleh data sebagai berikut:

Matematika Bisnis $(\mathrm{M})=600$ mahasiswa

Statistika Bisnis $(S)=400$ rnahasiswa

Matematika Bisnis dan Statistika Bisnis = 550 mahasiswa

Berapa peluang seorang mahasiswa yang mengikuti ujian mata kuliah Matematika Bisnis atau Statistika Bisnis?

\section{Penyelesaian :}

$$
\begin{aligned}
P(M \cup S) & =P(M)+P(S)-P(M \cap S) \\
& =0,6+0,4-0,55 \\
& =0,45
\end{aligned}
$$

Maka kemungkinan seorang mahasiswa mengikuti ujian mata kuliah matematika bisnis atau statistika bisnis adalah 0,45.

\section{Contoh 2}

Berapakah probabilitas seseorang mahasiswa lulus dalam ujian teori dan praktek statistika bisnis, dengan informasi sebagai berikut:

$\mathrm{P}($ Teori $)=\mathrm{P}(A)=0,35$

$P($ Praktek $)=P(B)=0,55$

$\mathrm{P}($ Teori atau Praktek $)=\mathrm{P}(A \cup B)=0,80$ 
Penyelesaian :

$$
\begin{aligned}
P(A \cup B) & =P(A)+P(B)-P(A \cap B) \\
0,80 & =0,35+0,55-P(A \cap B) \\
0,80 & =0,90-P(A \cap B) \\
P(A \cap B) & =0,90-0,80=0,10
\end{aligned}
$$

Maka kemungkinan seorang mahasiswa lulus dalam ujian teori dan praktek statistika bisnis adalah 0,10.

3. Peristiwa Independent (Bebas)

Yaitu suatu peristiwa yang tidak mempengaruhi peristiwa lainnya. Probabilitas peristiwa A dan B dikatakan independent bila kejadian peristiwa $B$ tidak dipengaruhi oleh terjadinya peristiwa A maupun sebaliknya.

Aturan yang digunakan sebagai berikut,

$\mathrm{P}(\mathrm{Adan} B)=P(A) \times P(B)$

Atau

$\mathrm{P}(\mathrm{A} \cap B)=P(A) \times P(B)$

\section{Contoh 1}

Pada sisi mata uang logam ada 2 sisi yaitu gambar dan angka. Berapakah probabilitas keluar gambar dan angka, bila sebuah mata uang dilempar sebanyak 2 kali?

\section{Penyelesaian :}

$$
\begin{aligned}
& P(\text { Gambar })=\frac{1}{2} \\
& P(\text { Angka })=\frac{1}{2}
\end{aligned}
$$


$P($ Gambar $\cap$ Angka $)=P($ Gambar $) \times P($ Angka $)$

$$
\begin{aligned}
& =\frac{1}{2} \times \frac{1}{2} \\
& =\frac{1}{4}
\end{aligned}
$$

\section{Contoh 2}

Sebuah dadu yang terdiri dari 6 sisi, dilemparkan sebanyak 2 kali. Peluang keluarnya sisi angka 3 pada pelemparan pertama dan sisi angka genap pada pelemparan kedua adalah ...

\section{Penyelesaian :}

$$
\begin{aligned}
& P(3)=\frac{1}{6} \\
& \begin{aligned}
P(\text { Genap })=\frac{3}{6} & \\
P(3 \cap \text { Genap }) & =P(3) \times P(\text { Genap }) \\
& =\frac{1}{6} \times \frac{3}{6} \\
& =\frac{3}{36}
\end{aligned}
\end{aligned}
$$

4. Peristiwa Dependent (tidak bebas / bersyarat) Yaitu suatu peristiwa tergantung pada peristiwa lain, disebut juga kejadian bersyarat. Dua peristiwa bersyarat apabila suatu peristiwa akan berpengaruh terhadap peristiwa lainnya. Probabilitas terjadinya suatu peristiwa itu sudah didahului dengan terjadinya peristiwa lainnya. Probabilitas bahwa A akan terjadi jika diketahui bahwa B telah terjadi maka dapat dirumuskan, 
$\mathrm{P}(B \mid A)=\frac{P(A \cap B)}{P(A)}$

\section{Contoh}

Kelulusan mata kuliah Statistika Bisnis diketahui 60\% sudah lulus ujian teori ataupun praktek, $40 \%$ mahasiswa lulus teori dan 30\% lulus praktek. Berapakah probabilitas mahasiswa lulus teori jika mahasiswa tersebut lulus praktek terlebih dahulu?

\section{Penyelesaian :}

$P($ lulusteori $)=P(A)=0,40$

$P($ luluspraktek $)=P(B)=0,30$

$P($ lulusteoriatau luluspraktek $)=P(A \cup B)=0,60$

Mencari peluang mahasiswa yang lulus teori dan lulus praktek terlebih dahulu,

$$
\begin{aligned}
P(A \cup B) & =P(A)+P(B)-P(A \cap B) \\
0,60 & =0,40+0,30-P(A \cap B) \\
0,60 & =0,70-P(A \cap B) \\
P(A \cap B) & =0,70-0,60 \\
& =0,10
\end{aligned}
$$

maka 


$$
\begin{aligned}
P(A \mid B) & =\frac{P(A \cap B)}{P(B)} \\
& =\frac{0,10}{0,30} \\
& =\frac{1}{3}=0,33
\end{aligned}
$$

\section{Teori Bayes}

Teori ini merupakan pengembangan dari hubungan bersyarat dimana peristiwa $\mathrm{B}$ akan didahului oleh peristiwa sebelurnnya yang mendahuluinya, peristiwa yang mendahuluinya adalah A1, A2, A3

dan seterusnya, artinya peristiwa yang mendahului dapat lebih dari satu peristiwa. Misalkan, seorang pedagang ingin rnembuka usaha kecil-kecilan, peristiwa yang mendahului adalah mencari modal, membeli gerobak, menyewa tempat, dan lainnya.

Secara umum teori Bayes dirumuskan sebagai,

$$
P(A \mid B)=\frac{P(B \mid A) P(A)}{P(B \mid A) P(A)+P\left(B \mid A^{\prime}\right) P\left(A^{\prime}\right)}
$$

Atau bila ada kejadian $A$ sebanyak $n$ maka persamaan Bayes menjadi,

$$
P\left(A_{i} \mid B\right)=\frac{P\left(B \mid A_{i}\right) P\left(A_{i}\right)}{\sum_{j} P\left(B \mid A_{j}\right) P\left(A_{j}\right)}
$$

\section{Contoh}


Perusahaan Zyu mempunyai 2 mesin yang dioperasikan untuk memenuhi permintaan. Mesin D1 dapat memproduksi $40 \%$ dan mesin D2 60\%. Dari kedua mesin tersebut ditemukan adanya output produk yang cacat mesin D1 ada 3\% dan mesin D2 ada 5\%. Jika diambil satu output secara random

a. Berapa probabilitas terambil output yang rusak?

b. Berapa probabilitas output yang dihasilkan oleh masingmasing mesin D1 dan D2?

\section{Penyelesaian :}

Prosentase produksi mesin

$P(D 1)=40 \%=0,4$

$P(D 2)=60 \%=0,6$

Prosentase output produk cacat

$$
\begin{aligned}
& P(C \mid D 1)=3 \%=0,03 \\
& P(C \mid D 2)=5 \%=0,05
\end{aligned}
$$

a. Probabilitas terambil output yang cacat

$$
\begin{aligned}
P(C) & =P(D 1) \times P(C \mid D 1)+P(D 2) \times P(C \mid D 2) \\
& =0,4 \times 0,03+0,6 \times 0,05 \\
& =0,012+0,030 \\
& =0,042
\end{aligned}
$$

b. Prosentase Output yang dihasilkan masing-masing mesin D1 dan D2 


$$
\begin{aligned}
P(D 1 \mid C) & =\frac{P(D 1) \times P(C \mid D 1)}{P(C)} \\
& =\frac{0,4 \times 0,03}{0,042} \\
& =0,286 \\
P(D 2 \mid C) & =\frac{P(D 2) \times P(C \mid D 2)}{P(C)} \\
& =\frac{0,6 \times 0,05}{0,042} \\
& =0,714
\end{aligned}
$$

\section{LATIHAN}

Kerjakan soal-soal di bawah ini!

1. Pemilik pabrik yang memproduksi barang $Z$, mengatakan bahwa terdapat $15 \%$ barang $Z$ yang rusak. Seorang membeli barang tersebut sebanyak 4 kali dan memilihnya secara acak.

Berapa besar probabilitas, jika :

a. Bahwa ada 2 barang yang rusak

b. Paling sedikit ada 1 yang rusak

c. Paling banyak ada 3 yang rusak

d. Yang rusak antara 2 dan 4

e. Yang rusak lebih kecil dari 3

2. Tabel berikut menunjukkan umur dan jenis kelamin dari para karyawan perhotelan di Sidoarjo,

\begin{tabular}{|c|c|c|c|}
\hline \multicolumn{1}{c|}{ Kelamin } & \multirow{2}{*}{ Pria $\left(\mathbf{B}_{\mathbf{1}}\right)$} & \multirow{2}{*}{ Wanita $\left(\mathbf{B}_{\mathbf{2}}\right)$} & \multirow{2}{*}{ Jumlah } \\
\hline$<20$ tahun $\left(\mathrm{A}_{1}\right)$ & 1900 & 1100 & 3000 \\
\hline $20-30 \operatorname{tahun}\left(\mathrm{A}_{2}\right)$ & 4200 & 1400 & 5600 \\
\hline$\leq 30$ tahun $\left(\mathrm{A}_{3}\right)$ & 900 & 500 & 1400 \\
\hline
\end{tabular}




\begin{tabular}{|c|c|c|c|}
\hline Jumlah & 7000 & 3000 & 10000 \\
\hline
\end{tabular}

Hitunglah :
a. $P\left(A_{1} B_{1}\right)$
b. $P\left(B_{1}\right), P\left(B_{1}\right)$
c. $P\left(A_{3} B_{2}\right)$
d. $P\left(A_{2}\right.$ atau $\left.A_{3}\right)$

3. Sebuah survey dilakukan terhadap 500 orang mahasiswa sebuah perguruan tinggi, dan didapatkan hasil sebagai berikut :

\begin{tabular}{|c|c|c|c|c|}
\hline \multirow{2}{*}{$\begin{array}{c}\text { Jenis } \\
\text { kelamin }\end{array}$} & \multicolumn{3}{|c|}{ Program Studi } & \multirow{2}{*}{$\begin{array}{l}\text { Tot } \\
\text { al }\end{array}$} \\
\hline & $\begin{array}{c}\text { Akuntan } \\
\text { si }\end{array}$ & $\begin{array}{c}\text { Manajem } \\
\text { en }\end{array}$ & $\begin{array}{c}\text { Magist } \\
\text { er }\end{array}$ & \\
\hline Laki-laki & 75 & 100 & 75 & 250 \\
\hline $\begin{array}{c}\text { Perempu } \\
\text { an }\end{array}$ & 125 & 100 & 25 & 250 \\
\hline Total & 200 & 200 & 100 & 500 \\
\hline
\end{tabular}

Tentukan probabilitas bahwa :

a. Seorang mahasiswa yang terpilih secara acak adalah perempuan!

b. Seorang mahasiswa yang terpilih secara acak dari program studi akuntansi atau manajemen!

c. Seorang mahasiswa yang terpilih secara acak berjenis kelamin laki-laki atau kuliah di program studi Magister! 


\section{BAB V}

\section{ANGKA INDEKS}

\section{A. PENDAHULUAN}

Angka indeks merupakan suatu metode analisis yang digunakan untuk mengetahui tentang fluktuasi harga berbagai komoditas perdagangan, yang selanjutnya juga dapat digunakan untuk mengetahui laju inflasi dari suatu periode waktu. Angka indeks adalah angka relative yang diperbandingkan dengan suatu periode awal.

Angka indeks dapat digunakan untuk membuat kebijakan-kabijakan yang harus diambil pemerintah dalam perekonomian. Contoh dengan mengetahui produksi barang tahun ini dibandingkan dengan tahun lalu. Perbandingan jumlah penduduk tahun ini dengan tahun lalu, hal ini digunakan pemerintah untuk membuat kebijakan-kebijakan terkait dengan kependudukan.

Dalam contoh lain, misalkan jika harga suatu produk di tahun 2018 adalah Rp 10.000,- kemudian pada tahun 2019 naik menjadi $\mathrm{Rp} 12.000$,- maka indeks harga barang tersebut pada tahun 2019 adalah $=\frac{12.000}{10.000} \times 100 \%=120 \%$

Jadi harga produk tersebut pada tahun 2019 mengalami kenaikan sebesar $20 \%$.

Dalam menentukan angka indeks ada beberapa hal penting yang harus diperhatikan, diantaranya : 
1. Mengetahui apa dan bagaimana cara mengukur angka indeks.

2. Sumber data harus berasal dari satu sumber, tiap jenis barang memiliki kualitas yang sama dan obyek yang dijadikan dasar harus mempresentasikan keseluruhan data.

3. Pemilihan dasar berdasarkan waktu kondisi perekonomian yang relative normal dan stabil, jarak tahun dasar dan tahun pembanding tidak terlalu jauh dan perlu memperhatikan kejadian-kejadian penting, misalnya kenaikan tariff listrik dan BBM.

\section{B. PENYAJIAN MATERI}

\section{Jenis-jenis Angka Indeks}

Ada beberapa jenis angka indeks, diantaranya adalah sebagai berikut :

a. Angka Indeks Harga

Indeks harga adalah angka yang menunjukkan perubahan pada harga-harga barang, baik harga untuk satu macam barang maupun berbagai macam barang dalam periode waktu.

Misalkan, indeks harga mobil niaga pada tahun 2018 adalah 118, maka dapat diartikan bahwa harga mobil niaga pada tahun ini adalah $18 \%$ lebih tinggi dari pada harga mobil niaga pada tahun dasar. Jika tahun yang akan datang indeks harga mobil niaga adalah 82 maka harga mobil niaga pada tahun depan akan mengalami penurunan sebesar $18 \%$ dari tahun dasar. 
Indeks harga mempunyai peran yang besar dalam perekonomian Negara, diantaranya yaitu :

1. Indeks harga merupakan petunjuk kondisi perekonomian Negara secara umum. Misalnya indeks harga grosir menggambarkan pertumbuhan perdagangan dalam satu Negara. Indeks harga pertanian dapat menggambarkan pertumbuhan dalam dunia pertanian.

2. Indeks harga dapat digunakan sebagai pembanding dengan harga barang yang ada di pasaran.

3. Indeks harga barang-barang konsumsi dapat digunakan sebagai patokan untuk menetapkan gaji buruh.

Ada beberapa jenis angka indeks harga yang telah ditetapkan oleh Badan Pusat Statistik, yaitu :

1. Angka Indeks Harga Perdagangan Besar (IHPB) Yaitu angka indeks yang menunjukkan perubahan pada harga pembelian barang oleh para pedagang besar dari konsumen. Satuan ukurannya adalah kuantitas borongan. Indeks harga perdagangan besar sangat bermanfaat bagi para pedagang besar, diantaranya :

a. Mengetahui perubahan-perubahan yang terjadi pada harga-harga pembelian barang dagangan, 
b. Sebagai dasar untuk memperkirakan kondisi harga di masa mendatang.

c. Mengetahui penyebab terjadinya perubahan pada harga, dengan demikian dapat digunakan untuk menetapkan harga dasar bagi para konsumen.

Besar kecilnya indeks harga perdagangan besar dipengaruhi oleh beberapa hal, yaitu :

a. Kenaikan biaya produksi

b. Kebijakan politik dagang

c. Kebijakan moneter

d. Perubahan nilai mata uang

Terdapat beberapa kemungkinan dalam penghitungan indeks harga, yaitu :

a. Jika indeks harga > 1 maka harga mengalami kenaikan.

b. Jika indeks harga $<1$ maka harga mengalami penurunan.

c. Jika indeks harga = 1 maka harga tetap.

2. Angka Indeks Konsumen

Yaitu angka indeks yang menunjukkan harga rata-rata barang dan jasa yang dikonsumsi oleh rumah tangga.

b. Angka Indeks Kuantitatif

Indeks Kuantitatif adalah angka yang menunjukkan perubahan banyaknya / jumlah barang yang dihasilkan, barang tersebut 
adalah barang yang sama untuk diekspor, dijual dan sebagainya dalam periode sama maupun berlainan.

\section{c. Angka Indeks Nilai}

Indeks Nilai adalah angka yang digunakan untuk mengetahui nilai barang sejenis atau sekumpulan barang dalam jangka waktu yang diketahui. Dapat juga diartikan sebagai perubahan nilai dari suatu barang baik yang diimpor maupun diekspor. Contoh indeks nilai impor beras, indeks impor kopi, indeks impor gula dan lain sebagainya.

\section{Metode Perhitungan Angka Indeks}

Ada beberapa metode yang digunakan dalam perhitungan angka indeks, yaitu :

\section{a. Indeks Relatif Sederhana}

Indeks relative sederhana adalah indeks yang tanpa memperhitungkan bobot tiap barang dan jasa, dimana setiap barang / jasa diberi bobot yang sama sehingga peran bahan pangan sama dengan bahan lain seperti elektronik.

Indeks relative sederhana dibedakan menjadi tiga yaitu :

1. Indeks Harga Relatif Sederhana Merupakan besarnya harga barang dan jasa tertentu dengan tahun dasar tanpa memberikan bobot komoditas.

Rumus :

$P_{\frac{n}{0}}=\frac{P_{n}}{P_{0}} \times 100$ 
Keterangan :

$P_{n}=$ harga barang dan jasa pada tahun ke-n

$P_{0}=$ harga barang dan jasa tahun dasar

Contoh :

Berikut ini adalah harga pulpen merek zyuman per satuan. Hitunglah angka indeks harga relative sederhana dengan menggunakan tahun dasar 2010

\begin{tabular}{|c|c|}
\hline Tahun & Harga pulpen \\
\hline 2010 & 2000 \\
\hline 2011 & 2250 \\
\hline 2012 & 2300 \\
\hline 2013 & 2200 \\
\hline 2014 & 2300 \\
\hline 2015 & 2350 \\
\hline 2016 & 2400 \\
\hline 2017 & 2400 \\
\hline 2018 & 2400 \\
\hline 2019 & 2500 \\
\hline
\end{tabular}

Penyelesaian :

Tahun $2011=\frac{2250}{2000} \times 100=112,5$

Tahun $2012=\frac{2300}{2000} \times 100=115$

Dan seterusnya, sehingga didapatkan indeks sebagai berikut,

\begin{tabular}{|c|c|c|}
\hline Tahun & Harga pulpen & Indeks \\
\hline 2010 & 2000 & 100 \\
\hline 2011 & 2250 & 112,5 \\
\hline
\end{tabular}




\begin{tabular}{|c|c|c|}
\hline 2012 & 2300 & 115 \\
\hline 2013 & 2200 & 110 \\
\hline 2014 & 2300 & 115 \\
\hline 2015 & 2350 & 117,5 \\
\hline 2016 & 2400 & 120 \\
\hline 2017 & 2400 & 120 \\
\hline 2018 & 2400 & 120 \\
\hline 2019 & 2500 & 125 \\
\hline
\end{tabular}

Harga pulpen per satuan dari tahun 2010 ke tahun 2019 mengalami kenaikan $25 \%$.

2. Indeks Kuantitatif Relatif Sederhana

Merupakan besarnya kuantitas barang dan jasa tahun tertentu dengan tahun dasar tanpa memberikan bobot komoditas.

Rumus :

$Q_{\frac{n}{0}}=\frac{Q_{n}}{Q_{0}} \times 100$

Keterangan :

$Q_{n}=$ kuantitas barang dan jasa pada tahun ke-n

$Q_{0}=$ kuantitas barang dan jasa tahun dasar

Contoh :

Berikut ini adalah kuantitas produksi pulpen merek zyuman. Hitunglah angka indeks kuantitatif relative sederhana dengan menggunakan tahun dasar 2010

\begin{tabular}{|c|c|}
\hline Tahun & Produksi pulpen \\
\hline 2010 & 1200 \\
\hline
\end{tabular}




\begin{tabular}{|l|l|}
\hline 2011 & 1300 \\
\hline 2012 & 1320 \\
\hline 2013 & 1330 \\
\hline 2014 & 1345 \\
\hline 2015 & 1366 \\
\hline 2016 & 1388 \\
\hline 2017 & 1400 \\
\hline 2018 & 1412 \\
\hline 2019 & 1455 \\
\hline
\end{tabular}

Penyelesaian :

Tahun $2011=\frac{1300}{1200} \times 100=108,3$

Tahun $2012=\frac{1320}{1200} \times 100=110$

Dan seterusnya, sehingga didapatkan indeks sebagai berikut,

\begin{tabular}{|c|c|c|}
\hline Tahun & $\begin{array}{c}\text { Produksi } \\
\text { pulpen }\end{array}$ & Indeks \\
\hline 2010 & 1200 & 100 \\
\hline 2011 & 1300 & 108,3 \\
\hline 2012 & 1320 & 110 \\
\hline 2013 & 1330 & 110,8 \\
\hline 2014 & 1345 & 112,1 \\
\hline 2015 & 1366 & 113,8 \\
\hline
\end{tabular}




\begin{tabular}{|l|l|l|}
\hline 2016 & 1388 & 115,7 \\
\hline 2017 & 1400 & 116,7 \\
\hline 2018 & 1412 & 117,7 \\
\hline 2019 & 1455 & 121,3 \\
\hline
\end{tabular}

Produksi pulpen merek zyuman dari tahun 2010 ke tahun 2019 mengalami kenaikan 21,3\%.

\section{Indeks Nilai Relatif Sederhana}

Merupakan besarnya nilai (harga dikalikan kuantitas) barang dan jasa tahun tertentu dengan tahun dasar tanpa memberikan bobot komoditas.

Rumus :

$V_{\frac{n}{0}}=\frac{V_{n}}{V_{0}}=\frac{P_{n} Q_{n}}{P_{0} Q_{0}} \times 100$

Keterangan :

$V_{n}=$ nilai barang dan jasa pada tahun ke-n

$V_{0}=$ nilai barang dan jasa tahun dasar

Contoh :

Berikut ini adalah harga dan kuantitas produksi pulpen merek zyuman. Hitunglah angka indeks nilai relative sederhana dengan menggunakan tahun dasar 2010

\begin{tabular}{|c|c|c|}
\hline Tahun & Harga & $\begin{array}{c}\text { Produksi } \\
\text { pulpen }\end{array}$ \\
\hline 2010 & 2000 & 1200 \\
\hline 2011 & 2250 & 1300 \\
\hline 2012 & 2300 & 1320 \\
\hline 2013 & 2200 & 1330 \\
\hline 2014 & 2300 & 1345 \\
\hline
\end{tabular}




\begin{tabular}{|l|l|l|}
\hline 2015 & 2350 & 1366 \\
\hline 2016 & 2400 & 1388 \\
\hline 2017 & 2400 & 1400 \\
\hline 2018 & 2400 & 1412 \\
\hline 2019 & 2500 & 1455 \\
\hline
\end{tabular}

Penyelesaian :

\begin{tabular}{|c|c|c|l|c|}
\hline $\begin{array}{c}\text { Tahu } \\
\mathbf{n}\end{array}$ & $\begin{array}{c}\text { Harg } \\
\mathbf{a}\end{array}$ & $\begin{array}{c}\text { Produk } \\
\text { si } \\
\text { pulpen }\end{array}$ & \multicolumn{1}{|c|}{ Nilai } & $\begin{array}{c}\text { Indek } \\
\text { s }\end{array}$ \\
\hline 2010 & 2000 & 1200 & $\begin{array}{l}240000 \\
0\end{array}$ & 100,0 \\
\hline 2011 & 2250 & 1300 & $\begin{array}{l}292500 \\
0\end{array}$ & 121,9 \\
\hline 2012 & 2300 & 1320 & $\begin{array}{l}303600 \\
0\end{array}$ & 126,5 \\
\hline 2013 & 2200 & 1330 & $\begin{array}{l}292600 \\
0\end{array}$ & 121,9 \\
\hline 2014 & 2300 & 1345 & $\begin{array}{l}309350 \\
0\end{array}$ & 128,9 \\
\hline 2015 & 2350 & 1366 & 321010 & 133,8 \\
\hline 2016 & 2400 & 1388 & $\begin{array}{l}333120 \\
0\end{array}$ & 138,8 \\
\hline 2017 & 2400 & 1400 & 336000 & 140,0 \\
\hline & & & 0 & \\
\hline
\end{tabular}




\begin{tabular}{|l|l|l|l|l|}
\hline 2018 & 2400 & 1412 & $\begin{array}{l}338880 \\
0\end{array}$ & 141,2 \\
\hline 2019 & 2500 & 1455 & $\begin{array}{l}363750 \\
0\end{array}$ & 151,6 \\
\hline
\end{tabular}

Nilai pulpen merek zyuman dari tahun 2010 ke tahun 2019 mengalami kenaikan 51,6\%.

\section{b. Indeks Agregatif Sederhana}

Angka indeks ini menekankan agregasi barang dan jasa lebih dari satu jenis, dimana harga, kuantitas dan nilai dari beberapa komoditas dijadikan satu, sehingga mendapatkan angka indeks yang mewakili agregasi tersebut.

Indeks agregatif sederhana dibedakan menjadi tiga, yaitu :

\section{Indeks Harga Agregatif Sederhana}

Merupakan perbandingan antara harga sejumlah barang dan jasa pada tahun berjalan terhadap tahun dasar, tanpa memberi bobot.

Rumus :

$A P_{\frac{n}{0}}=\frac{\sum P_{n}}{\sum P_{0}} \times 100$

Keterangan :

$\Sigma P_{n}=$ harga sejumlah barang dan jasa pada tahun ke-n

$\Sigma P_{0}=$ harga sejumlah barang dan jasa tahun dasar

Contoh : 
Hitunglah indeks harga agregatif sederhana dari 4 makanan yang dikonsumsi masyarakat, dengan tahun dasar 2017 sebagai berikut :

\begin{tabular}{|c|c|c|}
\hline Jenis & $\mathbf{2 0 1 7}$ & $\mathbf{2 0 1 9}$ \\
\hline Barang & Harga & Harga \\
\hline Telur & 1000 & 1200 \\
\hline Susu & 2000 & 2200 \\
\hline Keju & 3000 & 3100 \\
\hline Roti & 1500 & 1800 \\
\hline Total & $\mathbf{7 5 0 0}$ & $\mathbf{8 3 0 0}$ \\
\hline
\end{tabular}

Penyelesaian :

Maka indeks harga agregatif sederhana dengan tahun dasar 2017 adalah,

$$
\begin{aligned}
A P_{\frac{n}{0}} & =\frac{\sum P_{n}}{\sum P_{0}} \times 100 \\
& =\frac{8300}{7500} \times 100 \\
& =110,7
\end{aligned}
$$

Selama 3 tahun dari tahun 2017-2019 harga untuk keempat jenis makanan meningkat sebesar $10,7 \%$.

2. Indeks Kuantitatif Agregatif Sederhana Merupakan perbandingan antara kuantitas sejumlah barang dan jasa pada tahun berjalan terhadap tahun dasar, tanpa memberi bobot. 
Rumus :

$A Q_{\frac{n}{0}}=\frac{\sum Q_{n}}{\sum Q_{0}} \times 100$

Keterangan :

$\Sigma Q_{n}=$ kuantitas sejumlah barang dan jasa pada tahun ke-n

$\Sigma Q_{0}=$ kuantitas sejumlah barang dan jasa tahun dasar

Contoh :

Hitunglah indeks kuantitatif agregatif sederhana dari 4 makanan yang dikonsumsi masyarakat, dengan tahun dasar 2017 sebagai berikut :

\begin{tabular}{|c|c|c|}
\hline Jenis & $\mathbf{2 0 1 7}$ & $\mathbf{2 0 1 9}$ \\
\hline Barang & Kuantitas & Kuantitas \\
\hline Telur & 60 & 70 \\
\hline Susu & 80 & 85 \\
\hline Keju & 78 & 89 \\
\hline Roti & 94 & 100 \\
\hline Total & $\mathbf{3 1 2}$ & $\mathbf{3 4 4}$ \\
\hline
\end{tabular}

Penyelesaian :

Maka indeks kuantitatif agregatif sederhana dengan tahun dasar 2017 adalah, 


$$
\begin{aligned}
A Q_{\frac{n}{0}} & =\frac{\sum Q_{n}}{\sum Q_{0}} \times 100 \\
& =\frac{344}{312} \times 100 \\
& =110,3
\end{aligned}
$$

Selama 3 tahun dari tahun 2017-2019 kuantitas untuk ke0empat jenis makanan meningkat sebesar $10,3 \%$.

\section{Indeks Nilai Agregatif Sederhana}

Merupakan perbandingan antara nilai sejumlah barang dan jasa pada tahun berjalan terhadap tahun dasar, tanpa memberi bobot.

Rumus :

$$
A V_{\frac{n}{0}}=\frac{\sum P_{n} Q_{n}}{\sum P_{0} Q_{0}} \times 100
$$

Keterangan :

$\sum P_{n} Q_{n}=$ nilai sejumlah barang dan jasa pada tahun ke-n

$\sum P_{n} Q_{0}=$ nilai sejumlah barang dan jasa tahun dasar

Contoh :

Hitunglah indeks nilai agregatif sederhana dari 4 makanan yang dikonsumsi masyarakat, dengan tahun dasar 2017 sebagai berikut :

\begin{tabular}{|c|c|c|c|c|}
\hline Jenis & \multicolumn{2}{|c|}{2017} & \multicolumn{2}{c|}{2019} \\
\hline $\begin{array}{c}\text { Baran } \\
\text { g }\end{array}$ & $\begin{array}{c}\text { Harg } \\
\text { a }\end{array}$ & $\begin{array}{c}\text { Kuantit } \\
\text { as }\end{array}$ & $\begin{array}{c}\text { Harg } \\
\text { a }\end{array}$ & $\begin{array}{c}\text { Kuantit } \\
\text { as }\end{array}$ \\
\hline Telur & 1000 & 60 & 1200 & 70 \\
\hline
\end{tabular}




\begin{tabular}{|c|c|c|c|c|}
\hline Susu & 2000 & 80 & 2200 & 85 \\
\hline Keju & 3000 & 78 & 3100 & 89 \\
\hline Roti & 1500 & 94 & 1800 & 100 \\
\hline Total & $\mathbf{7 5 0 0}$ & $\mathbf{3 1 2}$ & $\mathbf{8 3 0 0}$ & $\mathbf{3 4 4}$ \\
\hline
\end{tabular}

Penyelesaian :

\begin{tabular}{|c|c|c|c|c|c|c|}
\hline Jenis & \multicolumn{3}{|c|}{2017} & \multicolumn{3}{c|}{$\mathbf{2 0 1 9}$} \\
\hline Barang & Harga & Kuantitas & Nilai & Harga & Kuantitas & Nilai \\
\hline Telur & 1000 & 60 & 60000 & 1200 & 70 & 84000 \\
\hline Susu & 2000 & 80 & 160000 & 2200 & 85 & 187000 \\
\hline Keju & 3000 & 78 & 234000 & 3100 & 89 & 275900 \\
\hline Roti & 1500 & 94 & 141000 & 1800 & 100 & 180000 \\
\hline Total & $\mathbf{7 5 0 0}$ & $\mathbf{3 1 2}$ & $\mathbf{5 9 5 0 0 0}$ & $\mathbf{8 3 0 0}$ & $\mathbf{3 4 4}$ & $\mathbf{7 2 6 9 0 0}$ \\
\hline
\end{tabular}

Maka indeks nilai agregatif sederhana dengan tahun dasar 2017 adalah,

$$
\begin{aligned}
A V_{\frac{n}{0}} & =\frac{\sum P_{n} Q_{n}}{\sum P_{0} Q_{0}} \times 100 \\
& =\frac{726900}{595000} \times 100 \\
& =122,2
\end{aligned}
$$

Selama 3 tahun dari tahun 2017-2019 nilai untuk keempat jenis makanan meningkat sebesar $22,2 \%$.

\section{c. Indeks Tertimbang}

Indeks tertimbang memberikan bobot yang berbeda pada setiap komponen, karena pada dasarnya setiap barang dan jasa memiliki tingkat utilitas (manfaat) yang berbeda. 
Indeks tertimbang biasa digunakan pada indeks agregat dimana banyak jenis komoditas yang memiliki bobot yang berbeda, Indeks tertimbang dihitung dengan beberapa cara sebagai berikut :

\section{Metode Laspeyres}

Angka indeks yang tertimbang dengan faktor penimbangnya kuantitas tahun dasar $\left(Q_{0}\right)$.

Rumus :

$I L=\frac{\sum P_{n} Q_{0}}{\sum P_{0} Q_{0}} \times 100 \%$

Keterangan :

$P_{n}=$ harga barang dan jasa pada tahun ke-n

$P_{0}=$ harga barang dan jasa pada tahun dasar

$Q_{0}=$ kuantitas barang dan jasa tahun dasar

Contoh :

Dibawah ini adalah data kursi yang diproduksi oleh PT Zyu Furniture beserta harga jualnya, serta jumlah produksi yang terjual dari tahun 2017-2019.

\begin{tabular}{|c|c|c|c|c|c|c|}
\hline \multirow{2}{*}{$\begin{array}{c}\text { kenis } \\
\text { kursi }\end{array}$} & \multicolumn{2}{|c|}{$\mathbf{2 0 1 7}$} & \multicolumn{2}{c|}{$\mathbf{2 0 1 8}$} & \multicolumn{2}{c|}{$\mathbf{2 0 1 9}$} \\
\cline { 2 - 7 } & $\mathbf{P}$ & $\mathbf{Q}$ & $\mathbf{P}$ & $\mathbf{Q}$ & $\mathbf{P}$ & $\mathbf{Q}$ \\
\hline Kecil & 30000 & 200 & 35000 & 250 & 40000 & 300 \\
\hline Sedang & 50000 & 250 & 55000 & 280 & 60000 & 320 \\
\hline Besar & 80000 & 150 & 90000 & 190 & 100000 & 200 \\
\hline
\end{tabular}

Berapa angka indeks kuantitas model Lanpeyres tahun 2018 dengan tahun dasar 2017?

Penyelesaian : 


$$
\begin{aligned}
I P & =\frac{\sum P_{n} Q_{0}}{\sum P_{0} Q_{0}} \times 100 \% \\
& =\frac{(35000.200)+(55000.250)+(90000.150)}{(30000.200)+(50000.250)+(80000.150)} \times 100 \% \\
& =\frac{34250000}{30500000} \times 100 \% \\
& =112,30 \%
\end{aligned}
$$

\section{Metode Paasche}

Angka indeks yang tertimbang dengan faktor penimbangnya kuantitas tahun ke-n $\left(Q_{n}\right)$.

Rumus :

$I P=\frac{\sum P_{n} Q_{n}}{\sum P_{0} Q_{n}} \times 100 \%$

Keterangan :

$P_{n}=$ harga barang dan jasa pada tahun ke-n

$P_{0}=$ harga barang dan jasa pada tahun dasar

$Q_{n}=$ kuantitas barang dan jasa tahun ke-n

Contoh :

Dibawah ini adalah data kursi yang diproduksi oleh PT Zyu Furniture beserta harga jualnya, serta jumlah produksi yang terjual dari tahun 2017-2019.

\begin{tabular}{|c|c|c|c|c|c|c|}
\hline \multirow{2}{*}{$\begin{array}{c}\text { Jenis } \\
\text { kursi }\end{array}$} & \multicolumn{2}{|c|}{$\mathbf{2 0 1 7}$} & \multicolumn{2}{c|}{$\mathbf{2 0 1 8}$} & \multicolumn{2}{c|}{$\mathbf{2 0 1 9}$} \\
\cline { 2 - 7 } & $\mathbf{P}$ & $\mathbf{Q}$ & $\mathbf{P}$ & $\mathbf{Q}$ & $\mathbf{P}$ & $\mathbf{Q}$ \\
\hline Kecil & 30000 & 200 & 35000 & 250 & 40000 & 300 \\
\hline Sedang & 50000 & 250 & 55000 & 280 & 60000 & 320 \\
\hline
\end{tabular}


\begin{tabular}{|l|l|l|l|l|l|l|}
\hline Besar & 80000 & 150 & 90000 & 190 & 100000 & 200 \\
\hline
\end{tabular}

Berapa angka indeks kuantitas model Paasche tahun 2018 dengan tahun dasar 2017?

Penyelesaian :

$$
\begin{aligned}
I P & =\frac{\sum P_{n} Q_{n}}{\sum P_{0} Q_{n}} \times 100 \% \\
& =\frac{(35000.250)+(55000.280)+(90000.190)}{(30000.250)+(50000.280)+(80000.190)} \times 100 \% \\
& =\frac{41250000}{36700000} \times 100 \% \\
& =112,40 \%
\end{aligned}
$$

\section{Metode Irving Fisher}

Merupakan angka indeks yang ideal, yaitu menghitung indeks kompromi dengan cara mencari rata-rata ukur dari Indeks Laspeyres dan Indeks Paasche.

Rumus :

$$
I F=\sqrt{I L \times I P}
$$

Keterangan :

IF = angka indeks Fisher

$I L=$ angka indeks Laspeyres

$I P=$ angka indeks Paasche

Contoh :

Dibawah ini adalah data kursi yang diproduksi oleh PT Zyu Furniture beserta harga jualnya, serta jumlah produksi yang terjual dari tahun 2017-2019. 


\begin{tabular}{|c|c|c|c|c|c|c|}
\hline Jenis & \multicolumn{2}{|c|}{$\mathbf{2 0 1 7}$} & \multicolumn{2}{c|}{$\mathbf{2 0 1 8}$} & \multicolumn{2}{c|}{$\mathbf{2 0 1 9}$} \\
\cline { 2 - 8 } kursi & P & Q & P & Q & P & Q \\
\hline Kecil & 30000 & 200 & 35000 & 250 & 40000 & 300 \\
\hline Sedang & 50000 & 250 & 55000 & 280 & 60000 & 320 \\
\hline Besar & 80000 & 150 & 90000 & 190 & 100000 & 200 \\
\hline
\end{tabular}

Berapa angka indeks kuantitas model Fisher tahun 2018 dengan tahun dasar 2017?

Penyelesaian :

$$
\begin{aligned}
I F & =\sqrt{I L \times I P} \\
& =\sqrt{112,30 \times 112,40} \% \\
& =112,35 \%
\end{aligned}
$$

\section{Metode Drobisch}

Merupakan kombinasi dari indeks Laspeyres dengan indeks Paasche atau rata-rata dari kedua indeks tersebut. Indeks Drobisch ini untuk memperkecil perbedaan dari indeks Laspeyres dan Paasche.

Rumus :

$I D=\frac{I L+I P}{2}$

Keterangan :

IF = angka indeks Fisher

$I L$ = angka indeks Laspeyres

$I P$ = angka indeks Paasche

Contoh : 
Dibawah ini adalah data kursi yang diproduksi oleh PT Zyu Furniture beserta harga jualnya, serta jumlah produksi yang terjual dari tahun 2017-2019.

\begin{tabular}{|c|c|c|c|c|c|c|}
\hline \multirow{2}{*}{$\begin{array}{c}\text { Jenis } \\
\text { kursi }\end{array}$} & \multicolumn{2}{|c|}{$\mathbf{2 0 1 7}$} & \multicolumn{2}{c|}{$\mathbf{2 0 1 8}$} & \multicolumn{2}{c|}{2019} \\
\cline { 2 - 7 } & $\mathbf{P}$ & $\mathbf{Q}$ & $\mathbf{P}$ & $\mathbf{Q}$ & $\mathbf{P}$ & $\mathbf{Q}$ \\
\hline Kecil & 30000 & 200 & 35000 & 250 & 40000 & 300 \\
\hline Sedang & 50000 & 250 & 55000 & 280 & 60000 & 320 \\
\hline Besar & 80000 & 150 & 90000 & 190 & 100000 & 200 \\
\hline
\end{tabular}

Berapa angka indeks kuantitas model Drobisch tahun 2018 dengan tahun dasar 2017?

Penyelesaian :

$$
\begin{aligned}
I D & =\frac{I L+I P}{2} \\
& =\frac{112,30+112,40}{2} \% \\
& =112,35 \%
\end{aligned}
$$

\section{Metode Edgeworth}

Merupakan model penghitungan indeks dengan menjumlahkan kuantitas dari tahun ke-n dengan kuantitas tahun dasar atau $\left(Q_{0}+Q_{n}\right)$ dan digunakan sebagai faktor pembanding.

Rumus :

$I E=\frac{\sum P_{n} \times\left(Q_{n}+Q_{0}\right)}{\sum P_{0} \times\left(Q_{n}+Q_{0}\right)} \times 100 \%$

Keterangan :

$I E$ = angka indeks Edgeworth

$P_{n}=$ harga barang dan jasa pada tahun ke-n 
$P_{0}=$ harga barang dan jasa pada tahun dasar

$Q_{n}=$ kuantitas barang dan jasa tahun ke-n

$Q_{0}=$ kuantitas barang dan jasa tahun dasar

Contoh :

Dibawah ini adalah data kursi yang diproduksi oleh PT Zyu Furniture beserta harga jualnya, serta jumlah produksi yang terjual dari tahun 2017-2019.

\begin{tabular}{|c|c|c|c|c|c|c|}
\hline \multirow{2}{*}{$\begin{array}{c}\text { Jenis } \\
\text { kursi }\end{array}$} & \multicolumn{2}{|c|}{$\mathbf{2 0 1 7}$} & \multicolumn{2}{c|}{$\mathbf{2 0 1 8}$} & \multicolumn{2}{c|}{$\mathbf{2 0 1 9}$} \\
\cline { 2 - 7 } & $\mathbf{P}$ & $\mathbf{Q}$ & $\mathbf{P}$ & $\mathbf{Q}$ & $\mathbf{P}$ & $\mathbf{Q}$ \\
\hline Kecil & 30000 & 200 & 35000 & 250 & 40000 & 300 \\
\hline Sedang & 50000 & 250 & 55000 & 280 & 60000 & 320 \\
\hline Besar & 80000 & 150 & 90000 & 190 & 100000 & 200 \\
\hline
\end{tabular}

Berapa angka indeks kuantitas model Edgeworth tahun 2018 dengan tahun dasar 2017?

Penyelesaian :

$$
\begin{aligned}
I E & =\frac{\sum P_{n} \times\left(Q_{n}+Q_{0}\right)}{\sum P_{0} \times\left(Q_{n}+Q_{0}\right)} \times 100 \% \\
& =\frac{(35000.450)+(55000.530)+(90000.340)}{(30000.450)+(50000.530)+(80000.340)} \times 100 \% \\
& =112,35 \%
\end{aligned}
$$

\section{LATIHAN}

Kerjakan soal-soal di bawah ini!

1. Berikut ini adalah data produksi dan data harga dari tiga produk yaitu A, B dan C untuk tahun 2017, 2018 dan 2019.

\begin{tabular}{|l|l|l|}
\hline & Produksi (satuan) & Harga per satuan \\
\hline
\end{tabular}




\begin{tabular}{|c|c|c|c|c|c|c|}
\hline $\begin{array}{c}\text { Produ } \\
\text { k }\end{array}$ & 2017 & 2018 & 2019 & $\begin{array}{c}201 \\
7\end{array}$ & $\begin{array}{c}201 \\
8\end{array}$ & $\begin{array}{c}201 \\
9\end{array}$ \\
\hline A & 9675 & 9717 & $\begin{array}{c}1043 \\
6\end{array}$ & 3,95 & 3,89 & 4,13 \\
\hline B & $\begin{array}{c}117, \\
7\end{array}$ & $\begin{array}{c}115, \\
5\end{array}$ & 115,5 & 61,5 & 62,2 & 59,7 \\
\hline C & $\begin{array}{c}77,9 \\
3\end{array}$ & $\begin{array}{c}74,3 \\
9\end{array}$ & 82,79 & 34,8 & 35,4 & 38,9 \\
\hline
\end{tabular}

Hitunglah :

a. Indeks harga relative sederhana A, B dan C untuk tahun 2018 dan 2019 dengan tahun dasar 2017.

b. Indeks kuantitatif relative sederhana A, B dan C untuk tahun 2018 dan 2019 dengan tahun dasar 2017.

c. Indeks nilai relative sederhana A, B dan C untuk tahun 2018 dan 2019 dengan tahun dasar 2017.

d. Indeks harga agregatif sederhana tahun 2018 dan 2019 dengan tahun dasar 2017.

e. Indeks kuantitatif agregatif sederhana tahun 2018 dan 2019 dengan tahun dasar 2017.

f. Indeks nilai agregatif sederhana tahun 2018 dan 2019 dengan tahun dasar 2017.

2. Berikut ini adalah data produksi dan data harga dari tiga produk yaitu A, B, C, D dan E untuk tahun 2017, 2018 dan 2019.

\begin{tabular}{|c|c|c|c|c|c|c|}
\hline \multirow{2}{*}{ Produk } & \multicolumn{3}{|c|}{ Produksi (satuan) } & \multicolumn{4}{c|}{ Harga per satuan } \\
\cline { 2 - 7 } & 2017 & 2018 & 2019 & 2017 & 2018 & 2019 \\
\hline
\end{tabular}




\begin{tabular}{|c|c|c|c|c|c|c|}
\hline $\mathrm{A}$ & 20 & 30 & 35 & 10 & 8 & 7 \\
\hline $\mathrm{B}$ & 35 & 25 & 15 & 12 & 15 & 20 \\
\hline $\mathrm{C}$ & 40 & 50 & 60 & 15 & 10 & 8 \\
\hline $\mathrm{D}$ & 30 & 25 & 20 & 5 & 7 & 10 \\
\hline $\mathrm{E}$ & 15 & 20 & 30 & 20 & 15 & 8 \\
\hline
\end{tabular}

Hitunglah :

a. Angka indeks tertimbang dengan rumus Laspeyres dan Paasche untuk tahun 2018 dan 2019 dengan tahun dasar 2017.

b. Angka indeks tertimbang dengan rumus Fisher dan Drobisch untuk tahun 2018 dan 2019 dengan tahun dasar 2017.

c. Angka indeks tertimbang dengan rumus Edgeworth untuk tahun 2018 dan 2019 dengan tahun dasar 2017.

\section{BAB VI}

\section{UJI NORMALITAS}

\section{A. PENDAHULUAN}

Sebelum pengolahan data dengan menggunakan pengujian inferensi parametrik maupun non parametrik maka data harus 
diuji normalitasnya terlebih dahulu. Terdapat kriteria untuk tahap pengujian inferensi yaitu statistik parametric tidak dapat digunakan jika data tidak normal. Dan jika data tidak normal maka pengujian dapat dilakukan dengan statistik non paramettik. Untuk melihat apakah data berdistribusi normal atau tidak, maka dapat menggunakan Chi kuadran ([?ㄹ).

\section{B. PENYAJIAN MATERI}

Pengujian normalitas data dengan ([? ${ }^{2}$ ) dilakukan dengan cara membandingkan kurva normal yang terbentuk dari data yang telah terkumpul dengan kurva normal.

Rumus dari Chi kuadran hitung ([? $\left.{ }^{2}\right)$ sebagai berikut, $\chi^{2}=\frac{\left(f_{i}-f_{h}\right)^{2}}{f_{h}}$

Keterangan :

? ${ }^{2}=$ chi kuadran hitung

$f_{i}=$ frekuensi yang diharapkan

$f_{h}=$ frekuensi / jumlah data hasil observasi

Dengan kriteria :

Chi kuadran hitung > chi kuadran table maka data tidak berdistribusi normal.

Chi kuadran hitung < chi kuadran table maka data berdistribusi normal.

Contoh 
Berikut adalah data nilai mata kuliah statistika bisnis mahasiswa dengan jumlah 120 orang.

\begin{tabular}{|c|c|c|c|c|c|c|c|c|c|}
\hline $\mathbf{N}$ & $\mathbf{N i l}$ & $\mathbf{N}$ & $\mathbf{N i l}$ & $\mathbf{N}$ & $\mathbf{N i l}$ & $\mathbf{N}$ & $\mathbf{N i l}$ & $\mathbf{N o}$ & $\mathbf{N i l}$ \\
$\mathbf{0}$ & $\mathbf{a i}$ & $\mathbf{0}$ & $\mathbf{a i}$ & $\mathbf{0}$ & $\mathbf{a i}$ & $\mathbf{0}$ & $\mathbf{a i}$ & & $\mathbf{a i}$ \\
\hline 1 & 80 & 2 & 75 & 4 & 80 & 7 & 66 & 97 & 70 \\
& & 5 & & 9 & & 3 & & & \\
\hline 2 & 77 & 2 & 69 & 5 & 78 & 7 & 60 & 98 & 69 \\
& & 6 & & 0 & & 4 & & & \\
\hline 3 & 80 & 2 & 70 & 5 & 77 & 7 & 70 & 99 & 70 \\
& & 7 & & 1 & & 5 & & & \\
\hline 4 & 78 & 2 & 75 & 5 & 79 & 7 & 71 & 10 & 70 \\
& & 8 & & 2 & & 6 & & 0 & \\
\hline 5 & 77 & 2 & 71 & 5 & 78 & 7 & 75 & 10 & 71 \\
& & 9 & & 3 & & 7 & & 1 & \\
\hline 6 & 79 & 3 & 70 & 5 & 80 & 7 & 70 & 10 & 75 \\
& & 0 & & 4 & & 8 & & 2 & \\
\hline 7 & 78 & 3 & 70 & 5 & 85 & 7 & 70 & 10 & 70 \\
& & 1 & & 5 & & 9 & & 3 & \\
\hline 8 & 80 & 3 & 75 & 5 & 81 & 8 & 69 & 10 & 81 \\
& & 2 & & 6 & & 0 & & 4 & \\
\hline 9 & 85 & 3 & 71 & 5 & 80 & 8 & 70 & 10 & 80 \\
& & 3 & & 7 & & 1 & & 5 & \\
\hline 1 & 81 & 3 & 70 & 5 & 77 & 8 & 70 & 10 & 81 \\
0 & & 4 & & 8 & & 2 & & 6 & \\
\hline 1 & 80 & 3 & 69 & 5 & 80 & 8 & 71 & 10 & 85 \\
1 & & 5 & & 9 & & 3 & & 7 & \\
\hline 1 & 77 & 3 & 70 & 6 & 78 & 8 & 75 & 10 & 87 \\
2 & & 6 & & 0 & & 4 & & 8 & \\
\hline
\end{tabular}




\begin{tabular}{|c|c|c|c|c|c|c|c|c|c|}
\hline 1 & 80 & 3 & 75 & 6 & 77 & 8 & 70 & 10 & 88 \\
3 & & 7 & & 1 & & 5 & & 9 & \\
\hline 1 & 77 & 3 & 71 & 6 & 69 & 8 & 69 & 11 & 90 \\
4 & & 8 & & 2 & & 6 & & 0 & \\
\hline 1 & 78 & 3 & 70 & 6 & 50 & 8 & 70 & 11 & 92 \\
5 & & 9 & & 3 & & 7 & & 1 & \\
\hline 1 & 79 & 4 & 69 & 6 & 50 & 8 & 70 & 11 & 91 \\
6 & & 0 & & 4 & & 8 & & 2 & \\
\hline 1 & 80 & 4 & 70 & 6 & 51 & 8 & 71 & 11 & 90 \\
7 & & 1 & & 5 & & 9 & & 3 & \\
\hline 1 & 85 & 4 & 75 & 6 & 56 & 9 & 75 & 11 & 87 \\
8 & & 2 & & 6 & & 0 & & 4 & \\
\hline 1 & 81 & 4 & 71 & 6 & 60 & 9 & 70 & 11 & 88 \\
9 & & 3 & & 7 & & 1 & & 5 & \\
\hline 2 & 80 & 4 & 70 & 6 & 61 & 9 & 69 & 11 & 90 \\
0 & & 4 & & 8 & & 2 & & 6 & \\
\hline 2 & 81 & 4 & 70 & 6 & 62 & 9 & 70 & 11 & 92 \\
1 & & 5 & & 9 & & 3 & & 7 & \\
\hline 2 & 70 & 4 & 69 & 7 & 66 & 9 & 70 & 11 & 87 \\
2 & & 6 & & 0 & & 4 & & 8 & \\
\hline 2 & 70 & 4 & 80 & 7 & 65 & 9 & 71 & 11 & 88 \\
3 & & 7 & & 1 & & 5 & & 9 & \\
\hline 2 & 71 & 4 & 77 & 7 & 65 & 9 & 75 & 12 & 95 \\
4 & & 8 & & 2 & & 6 & & 0 & \\
\hline
\end{tabular}

Langkah-langkah mencari nilai chi kuadran :

1. Menentukan jumlah kelas interval. 
Untuk pengujian normalitas dengan chi kuadran jumlah kelas ditetapkan 6 kelas sesuai dengan yang ada pada normal baku.

2. Menentukan panjang kelas interval $I=\frac{95-50}{6}=7,5=8$

3. Menghitung $f_{h}$ (frekuensi yang diharapkan)

Cara menghitung $f_{h}$ didasarkan pada prosentase luas tiap bidang kurva normal dikalikan jumlah data observasi (jumlah individu sampel). Dalam hal ini jumlah individu dalam sampel = 120. Luas kurva normal dibagi 6 bagian yaitu 2,75\%; 13,53\%; $34,13 \%$; 34,13\%; 13,53\%; 2,75\% seperti gambar berikut ini,

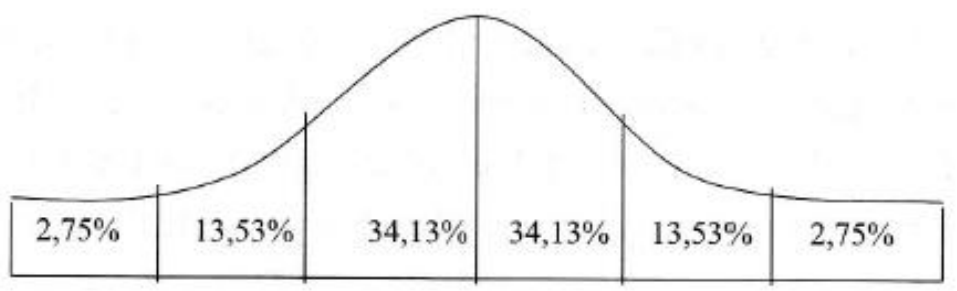

Terperinci, perhitungannya sebagai berikut :

a. Baris pertama : $2,75 \%$ x $120=3,24$ dibulatkan menjadi 3.

b. Baris kedua : $13,53 \% \times 120=16,24$ dibulatkan menjadi 16.

c. Baris ketiga : $34,13 \% \times 120=40,96$ dibulatkan menjadi 41.

d. Baris keempat : 34,13\% x $120=40,96$ dibulatkan menjadi 41.

e. Baris kelima : $13,53 \%$ x $120=16,24$ dibulatkan menjadi 16. 
f. Baris keenam : 2,75\% x $120=3,24$ dibulatkan menjadi 3.

4. Menyusun ke dalam table distribusi frekuensi, sekaligus table untuk menghitung chi kuadran hitung.

\begin{tabular}{|c|c|c|c|c|c|}
\hline Nilai & $f_{i}$ & $f_{h}$ & $f_{i}-f_{h}$ & $\left(f_{i}-f_{h}\right)^{\mathbf{2}}$ & $\begin{array}{c}\left(f_{i}-f_{h}\right)^{\mathbf{2}} / \\
f_{h}\end{array}$ \\
\hline $50-57$ & 4 & 3 & 1 & 1 & 0,33 \\
\hline $58-65$ & 8 & 16 & -8 & 64 & 4 \\
\hline $66-73$ & 49 & 41 & 8 & 64 & 1,56 \\
\hline $74-81$ & 44 & 41 & 3 & 9 & 0,22 \\
\hline $82-89$ & 11 & 16 & -5 & 25 & 1,56 \\
\hline $90-97$ & 4 & 3 & 1 & 1 & 0,33 \\
\hline jumlah & $\mathbf{1 2 0}$ & $\mathbf{1 2 0}$ & $\mathbf{0}$ & & $\mathbf{8 , 0 1}$ \\
\hline
\end{tabular}

Jadi chi kuadran hitung sebesar 8,01

5. Membandingkan chi kuadran hitung dengan chi kuadran table dengan dk (derajat kebebasan = jumlah kelas -1 ) yaitu $6-1=5$ dan didapatkan nilai chi kuadran table sebesar 11,07.

Dengan demikian berdasarkan kriteria chi kuadran hitung $(8,01)$ < chi kuadran table $(11,07)$ maka dikatakan data berdistribusi normal.

\section{LATIHAN}

1. Lakukan uji normalitas dari data penjualan suatu produk berikut :

$\begin{array}{llllllll}20 & 30 & 40 & 20 & 40 & 30 & 50 & 40 \\ 50 & 50 & 60 & 60 & 60 & 50 & 50 & 90 \\ 60 & 60 & 80 & 80 & 80 & 80 & 90 & 90\end{array}$


2. Berikut ini adalah data kuantitas produksi pulpen merek zyuman.

\begin{tabular}{|c|c|}
\hline Tahun & Produksi pulpen \\
\hline 2010 & 1200 \\
\hline 2011 & 1300 \\
\hline 2012 & 1320 \\
\hline 2013 & 1330 \\
\hline 2014 & 1345 \\
\hline 2015 & 1366 \\
\hline 2016 & 1388 \\
\hline 2017 & 1400 \\
\hline 2018 & 1412 \\
\hline 2019 & 1455 \\
\hline Apakah data tersebut merupakan data yang
\end{tabular}

berdistribusi normal?

\section{BAB VII}




\section{A. PENDAHULUAN}

Korelasi merupakan salah satu statistik inferensi yang akan menguji apakah dua variabel atau lebih mempunyai hubungan atau tidak. Terdapat tiga penggolongan berdasarkan jenis data dalam uji korelasi yaitu sebagai berikut :

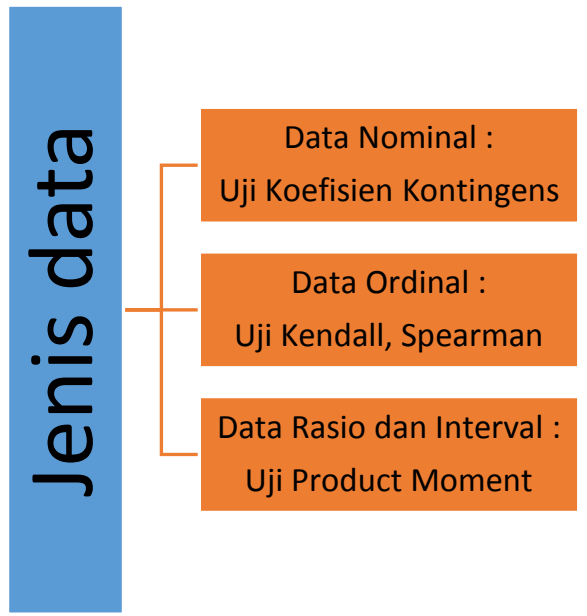

1. Uji Koefisien Kontingens digunakan untuk mencari korelasi jika data merupakan jenis data nominal (misalkan jenis kelamin, umur, pendidikan).

2. Uji Kendall dan Uji Spearman digunakan untuk mencari korelasi jika data merupakan jenis data ordinal (misalkan pendapat tentang kepuasan pelanggan).

3. Uji Product Moment digunakan untuk mencari korelasi jika data merupakan jenis data rasio (misalkan data penjualan)

Sementara itu, jika berdasarkan jenis data normal dan data tidak normal maka dapat digolongkan sebagai berikut : 


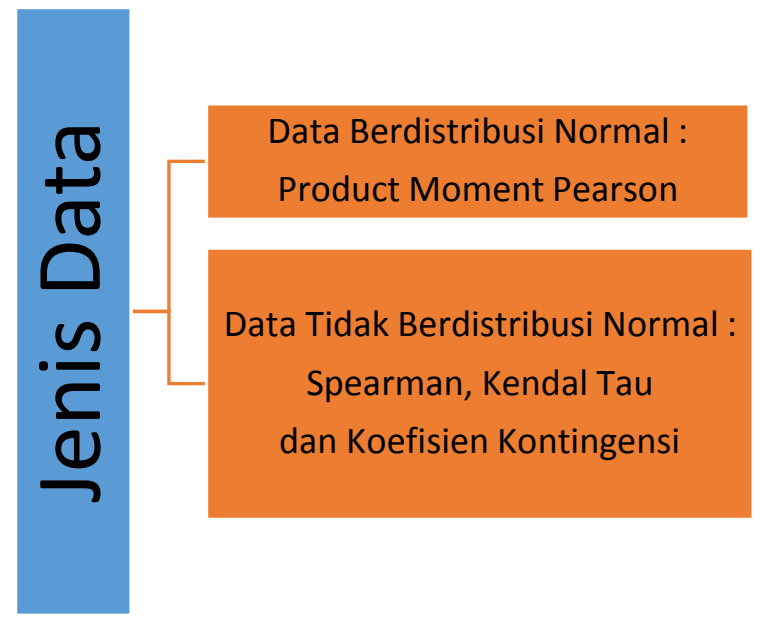

\section{B. PENYAJIAN MATERI}

\section{Statistik Parametrik}

Statistik parametrik digunakan untuk menguji hubungan diantara dua variabel dimana data harus berdistribusi normal. Jenis uji statistik parametrik untuk pengujian hubungan yaitu dengan menggunakan korelasi product moment pearson. Korelasi Product Moment Pearson

Pengujian ini digunakan untuk menguji dua variabel apakah ada hubungan atau tidak, dengan jenis data keduanya adalah sama yaitu rasio atau interval dan berdistribusi normal. Dirumuskan sebagai berikut :

$r_{x y}=\frac{\sum x y}{\sqrt{\sum x^{2} y^{2}}}$ 
Nilai $r$ dapat digunakan untuk :

a. Melihat ada atau tidaknya hubungan antara dua variable. Dengan kriteria :

Jika $r$ hitung $>r$ table (pada table $r$ ) maka $\mathrm{H}_{0}$ ditolak Jika $r$ hitung $<r$ table (pada table $r$ ) maka $\mathrm{H}_{0}$ diterima

b. Melihat nilai koefisien korelasi yang merupakan nilai untuk mengukur kuat tidaknya suatu hubungan antar variable. Koefisien korelasi memiliki nilai antara -1 hingga +1 . Sifat nilai koefisien korelasi antara nilai positif $(+)$ atau negatif (-). Arti nilai tersebut adalah

1. Korelasi positif $(+)$ berarti jika variable $\mathrm{x} 1$ mengalami kenaikan maka variable $x 2$ juga akan mengalami kenaikan, begitu juga sebaliknya.

2. Korelasi negatif (-) berarti jika variable $\mathrm{x} 1$ mengalami penurunan maka variable $\times 2$ mengalami kenaikan, begitu juga sebaliknya.

Disamping itu, nilai korelasi juga menggambarkan keeratan hubungan dan dapat dikelompokkan sebagai berikut :

1. Nilai $0,00 \leq r \leq 0,20$ maka korelasi memiliki keeratan yang sangat lemah.

2. Nilai $0,21 \leq r \leq 0,40$ maka korelasi memiliki keeratan yang lemah.

3. Nilai $0,41 \leq r \leq 0,70$ maka korelasi memiliki keeratan yang kuat.

4. Nilai $0,71 \leq r \leq 0,90$ maka korelasi memiliki keeratan yang sangat kuat. 
5. Nilai $0,91 \leq r \leq 0,99$ maka korelasi memiliki keeratan yang kuat sekali.

6. Nilai $r=1$ maka korelasi memiliki keeratan yang sempurna.

Contoh

Berikut disajikan data nilai statistic dan nilai IQ masing-masing mahasiswa kelas $A 1$,

\begin{tabular}{|c|c|c|}
\hline No & Nilai Statistik & Nllai IQ \\
\hline 1 & 50 & 100 \\
2 & 70 & 115 \\
3 & 60 & 100 \\
4 & 90 & 125 \\
5 & 70 & 115 \\
6 & 95 & 130 \\
7 & 80 & 120 \\
8 & 100 & 150 \\
9 & 50 & 100 \\
10 & 50 & 100 \\
\hline
\end{tabular}

Apakah terdapat hubungan antara nilai statistic dengan IQ mahasiswa di kelas A1?

Penyelesaian :

Membuat hipotesis kemungkinan jawaban

$\mathrm{H}_{0}=$ tidak terdapat hubungan antara nilai statistic dengan IQ mahasiswa kelas $\mathrm{A} 1$

$\mathrm{H}_{1}=$ terdapat hubungan antara nilai statistic dengan IQ mahasiswa kelas A1 
Mencari $r_{x y}$

\begin{tabular}{|c|c|c|c|c|c|c|c|}
\hline No & $\begin{array}{c}\text { Nilai } \\
\text { Statistik } \\
\text { (X) }\end{array}$ & $\begin{array}{c}\text { NIlai IQ } \\
\text { (Y) }\end{array}$ & $\begin{array}{c}(X-X \\
\text { rata- } \\
\text { rata })=X\end{array}$ & $\begin{array}{c}(Y-Y \\
\text { rata- } \\
\text { rata })=y\end{array}$ & $x^{\wedge} 2$ & $y^{\wedge} 2$ & xy \\
\hline 1 & 50 & 100 & $-21,5$ & $-15,5$ & 462,25 & 240,25 & 333,2 \\
\hline 2 & 70 & 115 & $-1,5$ & $-0,5$ & 2,25 & 0,25 & 0,75 \\
\hline 3 & 60 & 100 & $-11,5$ & $-15,5$ & 132,25 & 240,25 & 178,2 \\
\hline 4 & 90 & 125 & 18,5 & 9,5 & 342,25 & 90,25 & 175,7 \\
\hline 5 & 70 & 115 & $-1,5$ & $-0,5$ & 2,25 & 0,25 & 0,75 \\
\hline 6 & 95 & 130 & 23,5 & 14,5 & 552,25 & 210,25 & 340,7 \\
\hline 7 & 80 & 120 & 8,5 & 4,5 & 72,25 & 20,25 & 38,25 \\
\hline 8 & 100 & 150 & 28,5 & 34,5 & 812,25 & 1190,25 & 983,2 \\
\hline 9 & 50 & 100 & $-21,5$ & $-15,5$ & 462,25 & 240,25 & 333,2 \\
\hline 10 & 50 & 100 & $-21,5$ & $-15,5$ & 462,25 & 240,25 & 333,2 \\
\hline Total & 715 & 1155 & 0 & 0 & 3302,5 & 2472,5 & 2717 \\
\hline $\begin{array}{l}\text { Rata- } \\
\text { rata }\end{array}$ & 71,5 & 115,5 & & & & & \\
\hline
\end{tabular}

Maka nilai

$$
\begin{aligned}
r_{x y} & =\frac{2717}{\sqrt{(3302,5) \cdot(2472,5)}} \\
& =0,95
\end{aligned}
$$

Keputusannya :

a. Karena $r$ hitung $(0,95)>r$ table (pada table $r$ dengan $n=10$ dan derajat kepercayaan 5\%) $(0,497)$ maka $H_{0}$ ditolak sehingga dapat 
disimpulkan terdapat hubungan antara nilai statistic dengan IQ mahasiswa di kelas A1.

b. Karena nilai koefisien korelasi $r$ sebesar 0,95 maka dapat disimpulkan terdapat hubungan yang kuat sekali antara nilai statistic dengan IQ mahasiswa di kelas A1.

\section{Statistik Non Parametrik}

Statistik nonparametrik digunakan untuk menguji hubungan antara dua variabel dimana data harus berdistribusi normal. Jenis uji statistic nonparametrik yang digunakan untuk pengujian hubungan yaitu korelasi Spearman Rank, Kendal Tau, dan Koefisien Kontingensi.

a. Korelasi Spearman Rank

Pengujian ini digunakan untuk menguji ada atau tidaknya hubungan dua variabel, dengan jenis data ordinal dan data tidak harus berdistribusi normal. Dirumuskan sebagai berikut

$\rho=1-\frac{6 \sum b_{i}^{2}}{n\left(n^{2}-1\right)}$

Keterangan :

$\rho=$ rho $=$ koefisien korelasi

$n=$ jumlah sampel

$b_{i}=$ selisih rank antara $\times 1$ dan $\times 2$

Contoh

Sebuah survey dilakukan oleh tim dari Bank Artha Graha terhadap konsumennya dengan tujuan untuk mengetahui 
korelasi antara kepuasan konsumen dengan lokasi dari Bank Artha Graha.

Dimana :

Nilai kepuasan diberikan sebagai berikut :

1 = sangat tidak puas

2 = tidak puas

$3=$ puas

4 = sangat puas

Dan didapatkan data sebagai berikut :

\begin{tabular}{|c|l|c|l|c|}
\hline No & $\begin{array}{c}\text { Kepuasan } \\
\text { Konsumen }\end{array}$ & $\mathbf{X 1}$ & Lokasi & X2 \\
\hline 1 & Puas & 3 & Puas & 3 \\
\hline 2 & Puas & 3 & Puas & 3 \\
\hline 3 & Sangat Puas & 4 & Puas & 3 \\
\hline 4 & Puas & 3 & Puas & 3 \\
\hline 5 & Puas & 3 & Puas & 3 \\
\hline 6 & Puas & 3 & Puas & 3 \\
\hline 7 & Sangat Puas & 4 & Sangat Puas & 4 \\
\hline 8 & Sangat Puas & 4 & Sangat Puas & 4 \\
\hline 9 & Tidak Puas & 2 & Tidak Puas & 2 \\
\hline 10 & Tidak Puas & 2 & Tidak Puas & 2 \\
\hline
\end{tabular}

Penyelesaian :

\begin{tabular}{|c|c|c|c|c|c|c|}
\hline No & $\mathbf{X 1}$ & $\mathbf{X 2}$ & Rank X1 & Rank X2 & $\boldsymbol{b}_{\boldsymbol{i}}$ & $\boldsymbol{b}_{\boldsymbol{i}}^{\mathbf{2}}$ \\
\hline 1 & 3 & 3 & 6 & 5,5 & 0,5 & 0,25 \\
\hline 2 & 3 & 3 & 6 & 5,5 & 0,5 & 0,25 \\
\hline 3 & 4 & 3 & 2 & 5,5 & $-3,5$ & 12,25 \\
\hline 4 & 3 & 3 & 6 & 5,5 & 0,5 & 0,25 \\
\hline 5 & 3 & 3 & 6 & 5,5 & 0,5 & 0,25 \\
\hline
\end{tabular}




\begin{tabular}{|c|c|c|c|c|c|c|}
\hline 6 & 3 & 3 & 6 & 5,5 & 0,5 & 0,25 \\
\hline 7 & 4 & 4 & 2 & 1,5 & 0,5 & 0,25 \\
\hline 8 & 4 & 4 & 2 & 1,5 & 0,5 & 0,25 \\
\hline 9 & 2 & 2 & 9,5 & 9,5 & 0 & 0 \\
\hline 10 & 2 & 2 & 9,5 & 9,5 & 0 & 0 \\
\hline \multicolumn{5}{|c|}{ Jumlah } & 0 & 14 \\
\hline
\end{tabular}

Maka,

$$
\begin{aligned}
\rho & =1-\frac{6 \sum b_{i}^{2}}{n\left(n^{2}-1\right)} \\
& =1-\frac{6(14)}{10(99)} \\
& =1-0,085 \\
& =0,915
\end{aligned}
$$

Membuat hipotesis kemungkinan jawaban

$\mathrm{H}_{0}=$ tidak terdapat hubungan antara kepuasan konsumen dengan lokasi

$\mathrm{H}_{1}=$ terdapat hubungan antara kepuasan konsumen dengan lokasi

Dengan kriteria :

Jika $p$ hitung $>p$ table (pada table rho) maka $\mathrm{H}_{0}$ ditolak Jika $p$ hitung $<p$ table (pada table rho) maka $\mathrm{H}_{0}$ diterima Keputusannya :

Karena $p$ hitung $(0,915)>p$ table (pada table rho dengan $n=$ 10 dan derajat kepercayaan $5 \%)(0,648)$ maka $\mathrm{H}_{0}$ ditolak sehingga dapat disimpulkan terdapat hubungan antara kepuasan konsumen dengan lokasi. 
b. Korelasi Kendal Tau

Pengujian ini digunakan untuk menguji ada atau tidak adanya hubungan antara dua variable dengan jenis data ordinal dan tidak harus berdistribusi normal. Keunggulan korelasi ini adalah untuk menganalisis sampel yang jumlah anggotanya lebih dari 10. Dirumuskan sebagai berikut :

$\lambda=\frac{\sum A-\sum B}{\frac{n(n-1)}{2}}$

Keterangan :

$\lambda=$ koefisien korelasi Kendal Tau

$A=$ jumlah rangking atas

$B=$ jumlah rangking bawah

$n$ = jumlah anggota sampel

$z=\frac{\lambda}{\sqrt{\frac{2(2 n+5)}{9 n(n-1)}}}$

Contoh

Penelitian untuk mengetahui hubungan antara rangking kelas 9 SMP dengan rangking kelas 12 SMA, dilakukan dengan menggunakan sampel sebanyak 15 orang siswa, dan diperoleh data sebagai berikut :

\begin{tabular}{|c|c|c|}
\hline Sampel & $\begin{array}{c}\text { Rangking Kelas } \\
\text { 9 SMP }\end{array}$ & $\begin{array}{c}\text { Rangking Kelas } \\
\text { 12 SMA }\end{array}$ \\
\hline 1 & 1 & 2 \\
\hline 2 & 2 & 1 \\
\hline 3 & 3 & 4 \\
\hline
\end{tabular}




\begin{tabular}{|c|c|c|}
\hline 4 & 4 & 3 \\
\hline 5 & 5 & 7 \\
\hline 6 & 6 & 8 \\
\hline 7 & 7 & 9 \\
\hline 8 & 8 & 10 \\
\hline 9 & 9 & 15 \\
\hline 10 & 10 & 5 \\
\hline 11 & 11 & 6 \\
\hline 12 & 12 & 12 \\
\hline 13 & 13 & 14 \\
\hline 14 & 14 & 11 \\
\hline 15 & 15 & 16 \\
\hline
\end{tabular}

Langkah-langkahnya :

Judul Penelitian dapat dirumuskan

Apakah terdapat hubungan antara rangking kelas 9 SMP dengan rangking kelas 12 SMA. Penelitian dilakukan dengan menggunakan sampel siswa kelas 12 SMA?

Kemungkinan jawaban :

$\mathrm{H}_{0}=$ Tidak terdapat hubungan antara rangking kelas 9 SMP dengan rangking kelas 12 SMA. Penelitian dilakukan dengan menggunakan sampel siswa kelas 12 SMA

$\mathrm{H}_{1}=$ Terdapat hubungan antara rangking kelas 9 SMP dengan rangking kelas 12 SMA. Penelitian dilakukan dengan menggunakan sampel siswa kelas 12 SMA Maka, diperoleh data sebagai berikut :

\begin{tabular}{|c|c|c|c|c|}
\hline Sampel & $\begin{array}{c}\text { Rangking 1 } \\
\text { (R1) }\end{array}$ & $\begin{array}{c}\text { Rangking 2 } \\
\text { (R2) }\end{array}$ & $\begin{array}{c}\text { Jumlah } \\
\text { Ra }\end{array}$ & $\begin{array}{c}\text { Jumlah } \\
\text { Rb }\end{array}$ \\
\hline
\end{tabular}




\begin{tabular}{|c|c|c|c|c|}
\hline 1 & 1 & 2 & 13 & 1 \\
\hline 2 & 2 & 1 & 13 & 0 \\
\hline 3 & 3 & 4 & 11 & 1 \\
\hline 4 & 4 & 3 & 11 & 0 \\
\hline 5 & 5 & 7 & 8 & 2 \\
\hline 6 & 6 & 8 & 7 & 2 \\
\hline 7 & 7 & 9 & 6 & 2 \\
\hline 8 & 8 & 10 & 5 & 2 \\
\hline 9 & 9 & 15 & 1 & 5 \\
\hline 10 & 10 & 5 & 5 & 0 \\
\hline 11 & 11 & 6 & 4 & 0 \\
\hline 12 & 12 & 12 & 2 & 1 \\
\hline 13 & 13 & 14 & 1 & 1 \\
\hline 14 & 14 & 11 & 0 & 0 \\
\hline 15 & 15 & 16 & 0 & 0 \\
\hline & Total & & $\sum \mathrm{A}=87$ & $\sum \mathrm{B}=17$ \\
\hline
\end{tabular}

$$
\begin{aligned}
\lambda & =\frac{\sum A-\sum B}{\frac{n(n-1)}{2}} \\
& =\frac{87-17}{\frac{15(14)}{2}}=0,67
\end{aligned}
$$

Karena nilai koefisien korelasi Kendall Tau sebesar 0,67 maka dapat disimpulkan ada hubungan positif dan kuat antara rangking kelas 9 SMP dengan rangking kelas 12 SMA.

Mengambil keputusan dengan Pengujian Hipotesis:

$\mathrm{H}_{0}=$ Tidak terdapat hubungan antara rangking kelas $9 \mathrm{SMP}$ dengan rangking kelas 12 SMA. 
$\mathrm{H}_{1}=$ Terdapat hubungan antara rangking kelas 9 SMP dengan rangking kelas 12 SMA.

\section{Kriteria :}

Jika $Z_{\text {hitung }}>Z_{\text {tabel }}$ maka $\mathrm{H}_{0}$ ditolak

Jika $Z_{\text {hitung }}<Z_{\text {tabel }}$ maka $\mathrm{H}_{0}$ diterima

Mencari $Z_{\text {hitung }}$

$$
\begin{aligned}
z & =\frac{\lambda}{\sqrt{\frac{2(2 n+5)}{9 n(n-1)}}} \\
& =\frac{0,67}{\sqrt{\frac{2(30+5)}{135(15-1)}}} \\
& =3,46
\end{aligned}
$$

Karena $Z_{\text {hitung }}(3,46)>Z_{\text {tabel }}(1,65)$ maka $H_{0}$ ditolak dan $H_{1}$ diterima yang artinya terdapat hubungan antara rangking kelas 9 SMP dengan rangking kelas 12 SMA

c. Korelasi Koefisien Kontingensi

Pengujian korelasi ini digunakan untuk menguji ada tidaknya hubungan dua variabel dengan jenis data nominal dan tidak harus berdistribusi normal. Dirumuskan sebagai berikut : 
$\chi^{2}=\sum_{i=1}^{r} \sum_{j=1}^{k} \frac{\left(O P_{i j}+E_{i j}\right)^{2}}{E P_{i j}}$
dan
$C=\sqrt{\frac{\chi^{2}}{n+\chi^{2}}}$

Keterangan :

$C=$ koefisien kontingensi

$\chi^{2}=$ chi kuadran

$n \quad$ = jumlah sampel

Contoh

Untuk mengetahui hubungan antara tingkat pendidikan dengan profesi maka diambil sampel sebagai berikut :

\begin{tabular}{|c|c|c|}
\hline Sampel & $\begin{array}{c}\text { Tingkat } \\
\text { Pendidikan }\end{array}$ & Profesi \\
\hline 1 & SMA & $\begin{array}{c}\text { Ibu Rumah } \\
\text { Tangga } \\
\text { Ibu Rumah } \\
\text { Tangga }\end{array}$ \\
\hline 2 & SMA & $\begin{array}{c}\text { Ibu Rumah } \\
\text { Tangga }\end{array}$ \\
\hline 3 & SMA & Karyawan \\
\hline 4 & S1 & Karyawan \\
\hline 5 & S1 & Dosen \\
\hline 6 & S2 & Menteri \\
\hline 7 & S3 & Karyawan \\
\hline 8 & S1 \\
\hline
\end{tabular}




\begin{tabular}{|c|c|c|}
\hline 9 & S1 & Karyawan \\
\hline 10 & S2 & Dosen \\
\hline 11 & S1 & $\begin{array}{c}\text { Ibu Rumah } \\
\text { Tangga }\end{array}$ \\
\hline 12 & S1 & $\begin{array}{c}\text { Ibu Rumah } \\
\text { Tangga }\end{array}$ \\
\hline 13 & S2 & $\begin{array}{c}\text { Ibu Rumah } \\
\text { Tangga }\end{array}$ \\
\hline 14 & S3 & $\begin{array}{c}\text { Ibu Rumah } \\
\text { Tangga }\end{array}$ \\
\hline 15 & SMA & Karyawan \\
\hline 16 & S2 & Karyawan \\
\hline 17 & S3 & Karyawan \\
\hline 18 & S3 & Dosen \\
\hline 19 & $\mathrm{~S} 2$ & Menteri \\
\hline 20 & SMA & $\begin{array}{c}\text { Ibu Rumah } \\
\text { Tangga }\end{array}$ \\
\hline 21 & SMA & $\begin{array}{c}\text { Ibu Rumah } \\
\text { Tangga }\end{array}$ \\
\hline 22 & SMA & $\begin{array}{c}\text { Ibu Rumah } \\
\text { Tangga }\end{array}$ \\
\hline 23 & S1 & Karyawan \\
\hline 24 & S1 & Karyawan \\
\hline 25 & S2 & Dosen \\
\hline 26 & S3 & Menteri \\
\hline 27 & S1 & Karyawan \\
\hline 28 & S1 & Karyawan \\
\hline 29 & S1 & Karyawan \\
\hline
\end{tabular}

Kemudian dibuat tabulasinya sebagai berikut,

\begin{tabular}{|c|c|c|c|c|c|}
\hline \multirow{2}{*}{ Profesi } & \multicolumn{5}{|c|}{ Pendidikan } \\
\cline { 2 - 6 } & SMA & S1 & S2 & S3 & Jumlah \\
\hline
\end{tabular}




\begin{tabular}{|l|c|c|c|c|c|}
\hline $\begin{array}{l}\text { Ibu rumah } \\
\text { tangga }\end{array}$ & 6 & 2 & 1 & 1 & 10 \\
\hline Karyawan & 1 & 8 & 1 & 1 & 11 \\
\hline Dosen & 0 & 0 & 4 & 1 & 5 \\
\hline Menteri & 0 & 0 & 1 & 2 & 3 \\
\hline Jumlah & 7 & 10 & 7 & 5 & 29 \\
\hline
\end{tabular}

Langkah-langkahnya :

Sehingga dapat dirumuskan :

Apakah terdapat hubungan antara tingkat pendidikan dengan profesi?

Kemungkinannya

$\mathrm{H}_{0}=$ Tidak terdapat hubungan antara tingkat pendidikan dengan profesi.

$\mathrm{H}_{1}=$ Terdapat terdapat hubungan antara tingkat pendidikan dengan profesi.

Mengambil keputusan / Pengujian Hipotesis

Keempat sampel yang berprofesi sebagai ibu rumah tangga adalah :

$$
\frac{6+2+1+1}{29}=\frac{10}{29}=0,345
$$

Keempat sampel yang berprofesi sebagai karyawan adalah :

$$
\frac{1+8+1+1}{29}=\frac{11}{29}=0,379
$$

Keempat sampel yang berprofesi sebagai dosen adalah :

$$
\frac{0+0+4+1}{29}=\frac{5}{29}=0,172
$$


Keempat sampel yang berprofesi sebagai menteri adalah :

$$
\frac{0+0+1+2}{29}=\frac{3}{29}=0,103
$$

Dengan masing-masing $f_{h}$ (frekuensi yang diharapkan) yaitu :

a. Profesi ibu rumah tangga

1. $f_{h} \mathrm{SMA}=0,345 \times 7=2,415$

2. $f_{h} \mathrm{~S} 1=0,345 \times 10=3,45$

3. $f_{h} \mathrm{~S} 2=0,345 \times 7=2,415$

4. $f_{h} \mathrm{~S} 3=0,345 \times 5=1,725$

Total 10,005

b. Profesi karyawan

1. $f_{h} \mathrm{SMA}=0,379 \times 7=2,653$

2. $f_{h} \mathrm{~S} 1=0,379 \times 10=3,79$

3. $f_{h} \mathrm{~S} 2=0,379 \times 7=2,653$

4. $f_{h} \mathrm{~S} 3=0,379 \times 5=1,895$

Total 10,991

c. Profesi dosen

1. $f_{h} \mathrm{SMA}=0,172 \times 7=1,204$

2. $f_{h} \mathrm{~S} 1=0,172 \times 10=1,72$

3. $f_{h} \mathrm{~S} 2=0,172 \times 7=1,204$

4. $f_{h} \mathrm{~S} 3=0,172 \times 5=0,86$

Total 4,988

d. Profesi menteri

1. $f_{h} \mathrm{SMA}=0,103 \times 7=0,721$

2. $f_{h} \mathrm{~S} 1=0,103 \times 10=1,03$

3. $f_{h} \mathrm{~S} 2=0,103 \times 7=0,721$

4. $f_{h} \mathrm{~S} 3=0,103 \times 5=0,515$ 
Total 2,987

\begin{tabular}{|c|c|c|c|c|c|c|c|c|c|}
\hline \multirow{3}{*}{$\begin{array}{c}\text { Profesi } \\
\text { Ibu } \\
\text { rumah } \\
\text { tangga }\end{array}$} & \multicolumn{9}{|c|}{ Pendidikan } \\
\hline & \multicolumn{2}{|c|}{ SMA } & \multicolumn{2}{|c|}{ S1 } & \multicolumn{2}{|c|}{ S2 } & \multicolumn{2}{|c|}{ S3 } & $\begin{array}{c}\text { Juml } \\
\text { ah }\end{array}$ \\
\hline & 6 & $\begin{array}{c}2,41 \\
5\end{array}$ & 2 & $\begin{array}{c}3,4 \\
5\end{array}$ & 1 & $\begin{array}{c}2,41 \\
5\end{array}$ & 1 & $\begin{array}{c}1,72 \\
5\end{array}$ & 10 \\
\hline $\begin{array}{c}\text { Karyaw } \\
\text { an }\end{array}$ & 1 & $\begin{array}{c}2,65 \\
3\end{array}$ & 8 & $\begin{array}{c}3,7 \\
9\end{array}$ & 1 & $\begin{array}{c}2,65 \\
2\end{array}$ & 1 & $\begin{array}{c}1,89 \\
5\end{array}$ & 11 \\
\hline Dosen & 0 & $\begin{array}{c}1,20 \\
4\end{array}$ & 0 & $\begin{array}{c}1,7 \\
2\end{array}$ & 4 & $\begin{array}{c}1,20 \\
4\end{array}$ & 1 & 0,86 & 5 \\
\hline $\begin{array}{c}\text { Menter } \\
\mathrm{i}\end{array}$ & 0 & $\begin{array}{c}0,72 \\
1\end{array}$ & 0 & $\begin{array}{c}1,0 \\
3\end{array}$ & 1 & $\begin{array}{c}0,72 \\
1\end{array}$ & 2 & $\begin{array}{c}0,51 \\
5\end{array}$ & 3 \\
\hline Jumlah & 7 & & $\begin{array}{l}1 \\
0\end{array}$ & & 7 & & 5 & & 29 \\
\hline
\end{tabular}

Maka,

$\chi^{2}=\sum_{i=1}^{r} \sum_{j=1}^{k} \frac{\left(O P_{i j}+E_{i j}\right)^{2}}{E P_{i j}}=26,59$

Kriteria :

Jika $\chi_{\text {hitung }}^{2}>\chi_{\text {tabel }}^{2}$ maka $\mathrm{H}_{0}$ ditolak

Jika $\chi_{\text {hitung }}^{2}<\chi_{\text {tabel }}^{2}$ maka $\mathrm{H}_{0}$ diterima

Karena nilai $\chi_{\text {hitung }}^{2}(26,59)>\chi_{\text {tabel }}^{2}(16,92)$ maka $\mathrm{H}_{0}$ ditolak artinya ada hubungan antara tingkat pendidikan dengan profesi

Mencari nilai korelasi koefisien kontingensi 


$$
\begin{aligned}
C & =\sqrt{\frac{\chi^{2}}{n+\chi^{2}}} \\
& =\sqrt{\frac{26,59}{29+26,59}} \\
& =0,691
\end{aligned}
$$

Karena didapatkan nilai korelasinya sebesar 0,691 maka artinya ada hungan yang positif dan kuat antara tingkat pendidikan dan profesi.

\section{LATIHAN}

1. Seorang peneliti akan melakukan penelitian untuk mengetahui seberapa kuat hubungan antara besarnya pendapatan seseorang dengan pengeluaran (konsumsi) per bulan. Diambil 6 orang sebagai sampel dan diwawancarai, akhirnya diperoleh data sebagai berikut,

$X$ (pendapatan) : 800900800600700700 (ribuan) $Y$ (konsumsi) : :300 300200100200100 (ribuan)

Hitung koefisien korelasi dan simpulkan!

2. Jika $X$ adalah nilai ujian Matematika Bisnis mahasiswa Manajemen dan $Y$ adalah nilai ujian Statistik Bisnis

\begin{tabular}{|c|c|c|c|c|c|}
\hline \multirow[b]{2}{*}{$\begin{array}{c}\text { Statistik } \\
\text { Bisnis }\end{array}$} & \multicolumn{5}{|c|}{ Matematika Bisnis } \\
\hline & $1-20$ & $\begin{array}{c}21- \\
40\end{array}$ & $\begin{array}{c}41- \\
60\end{array}$ & $\begin{array}{c}61- \\
80\end{array}$ & $\begin{array}{l}81- \\
100\end{array}$ \\
\hline $1-20$ & 2 & 4 & 3 & & \\
\hline $21-40$ & & 5 & 4 & 3 & \\
\hline
\end{tabular}
mahasiswa Manajemen. Hasil ujian tersebut sudah dikelompokkan dalam tabel berikut : 


\begin{tabular}{|c|l|l|l|l|l|}
\hline $41-60$ & & 2 & 6 & 8 & 3 \\
$61-80$ & & & 2 & 4 & 2 \\
$81-100$ & & & 1 & 3 & 5 \\
\hline
\end{tabular}

Angka dalam tabel menunjukkan banyaknya mahasiswa. Tentukan hubungan antara nilai Matematika Bisnis dan Statistik Bisnis!

3. Berikut ini adalah tabel pasangan data antara $X=$ biaya promosi (jutaan rupiah) dan $Y=$ nilai penjualan (jutaan rupiah)!

\begin{tabular}{|c|l|l|l|l|l|l|l|l|}
\hline$X$ & 20 & 16 & 34 & 23 & 27 & 32 & 18 & 22 \\
\hline$Y$ & 64 & 61 & 84 & 70 & 88 & 92 & 72 & 77 \\
\hline
\end{tabular}

Hitunglah koefisien korelasi Rank (peringkat) dan simpulkan!

4. Ingin diketahui apakah ada hubungan antara tingkat pendapatan penduduk Sidoarjo dengan seringnya orang berwisata ke Trawas. Untuk tujuan tersebut, 400 orang penduduk Sidoarjo secara random diwawancarai, mengenai tingkat pendapatannya (rendah, menengah dan tinggi) dan juga mengenai seringnya berwisata ke Trawas (tidak pernah, jarang, sering sekali). Hasil wawancara tersebut adalah sebagai berikut :

\begin{tabular}{|c|c|c|c|}
\hline \multirow{2}{*}{ Pendapatan } & \multicolumn{3}{|c|}{ Ke Trawas } \\
\cline { 2 - 4 } & $\begin{array}{c}\text { Tidak } \\
\text { pernah }\end{array}$ & Jarang & $\begin{array}{c}\text { Sering } \\
\text { sekali }\end{array}$ \\
\hline Rendah & 77 & 13 & 8 \\
Menengah & 145 & 58 & 27 \\
Tinggi & 21 & 32 & 19 \\
\hline
\end{tabular}

Hitunglah koefisien korelasinya dan simpulkan! 


\section{BAB VIII}

\section{REGRESI LINIER}

\section{A. PENDAhUluAN}

Regresi bertujuan untuk mengetahui pengaruh antara variabel satu dengan variabel lain. Variabel yang dipengaruhi disebut variable tergantung atau dependen, sedang variabel yang rnempengaruhi disebut variabel bebas atau variabel independen. Pada bab ini akan dibahas regresi dibedakan menjadi 2 yaitu:

1. Regresi linier sederhana

2. Regresi linier berganda

\section{B. PENYAJIAN MATERI}

\section{Regresi Linier Sederhana}

Regresi linier sederhana merupakan regresi yang rnerniliki satu variabel dependen dan satu variable independent. Model persarnaan legresi linier sederhana dirumuskan sebagai berikut :

$$
Y=a+b X
$$

Keterangan :

$Y=$ subyek dalam variable dependen yang diprediksi

$a=$ harga $Y$ ketika harga $X=0$ (harga constant) 
b = angka arah atau koefisien regresi, yang menunjukkan angka peningkatan ataupun penurunan variabel dependen yang didasarkan pada perubahan variabel indepennden. Bila $(+)$ arah garis naik, dan bila (-) maka arah garis turun.

$X=$ Subyek pada variabel independen yang mempunyai nilai tertentu.

Dimana nilai $a$ dan $b$ diperoleh dari, $b=\frac{n \sum x y-\sum x \sum y}{n \sum x^{2}-\left(\sum x\right)^{2}}$
dan
$a=\frac{\sum y-b \sum x}{n}$

\section{Contoh}

Jika $X$ adalah persentase kenaikan biaya iklan dan $Y$ persentase kenaikan penjualan, sebagaimana data pada tabel berikut :

\begin{tabular}{|c|c|}
\hline $\begin{array}{c}\text { Persentase kenaikan } \\
\text { biaya iklan }(\boldsymbol{X})\end{array}$ & $\begin{array}{c}\text { Persentase kenaikan } \\
\text { penjualan }(\boldsymbol{Y})\end{array}$ \\
\hline 1 & 2 \\
\hline 2 & 4 \\
\hline 4 & 5 \\
\hline 5 & 7 \\
\hline 7 & 8 \\
\hline 9 & 10 \\
\hline 10 & 12 \\
\hline 12 & 14 \\
\hline
\end{tabular}

Maka tentukan persamaan regresi linier sederhana dan ramalkan persentase kenaikan penjualan jika biaya iklan dinaikkan menjadi 15\%! 
Penyelesaian :

\begin{tabular}{|c|c|c|c|}
\hline $\boldsymbol{X}$ & $\boldsymbol{Y}$ & $\boldsymbol{X Y}$ & $\boldsymbol{X}^{\mathbf{2}}$ \\
\hline 1 & 2 & 2 & 1 \\
\hline 2 & 4 & 8 & 4 \\
\hline 4 & 5 & 20 & 16 \\
\hline 5 & 7 & 35 & 25 \\
\hline 7 & 8 & 56 & 49 \\
\hline 9 & 10 & 90 & 81 \\
\hline 10 & 12 & 120 & 100 \\
\hline 12 & 14 & 168 & 144 \\
\hline $\mathbf{5 0}$ & $\mathbf{6 2}$ & $\mathbf{4 9 9}$ & $\mathbf{1 4 4}$ \\
\hline
\end{tabular}




$$
\begin{aligned}
b & =\frac{n \sum X_{i} Y_{i}-\sum X_{i} \sum Y_{i}}{n \sum X_{i}^{2}-\left(\sum X_{i}\right)^{2}} \\
& =\frac{8(499)-50(62)}{8(420)-(50)^{2}} \\
& =\frac{3992-3100}{3360-2500} \\
& =\frac{892}{860}=1,04 \\
\bar{Y} & =\frac{\sum Y_{i}}{n}=\frac{62}{8}=7,75 \\
\bar{X} & =\frac{\sum X}{n}=\frac{50}{8}=6,25 \\
a & =\bar{Y}-b \bar{X}=7,75-1,04(6,25) \\
& =1,25
\end{aligned}
$$

Maka didapatkan persamaan regresi linier sederhananya adalah

$$
Y=1,25+1,04 X
$$

Sehingga untuk biaya iklan 15\%, akan diramalkan persentase hasil penjualannya menjadi,

$$
\begin{aligned}
Y & =1,25+1,04 X \\
& =1,25+1,04(15) \\
& =1,25+15,6 \\
& =16,85 \%
\end{aligned}
$$

2. Regresi Linier Berganda 
Regresi linier berganda merupakan regresl yang memiliki satu vanabel dependen dan dua atau lebih variabel independent. Model persamaan regresi linier berganda dirumuskan rumus sebagau benkut :

$$
Y=a+b_{1} X_{1}+b_{2} X_{2}
$$

Keterangan :

$Y=$ subyek dalam variable dependen yang diprediksi

$a=$ harga konstanta

$b_{1}=$ koefisien regresi pertama

$b_{2}=$ koefisien regresi kedua

$X_{1}=$ variable independent pertama

$X_{2}=$ variable independent kedua

Dimana nilai $a, b_{1}$, dan $b_{2}$ diperoleh dari,

$$
\begin{aligned}
& b_{1}=\frac{\sum x_{1} y \sum x_{2}{ }^{2}-x_{2} y \sum x_{1} x_{2}}{\sum x_{1}{ }^{2} \sum x_{2}{ }^{2}-\left(\sum x_{1} x_{2}\right)^{2}} \\
& b_{2}=\frac{\sum x_{2} y \sum x_{1}{ }^{2}-x_{1} y \sum x_{1} x_{2}}{\sum x_{1}{ }^{2} \sum x_{2}{ }^{2}-\left(\sum x_{1} x_{2}\right)^{2}}
\end{aligned}
$$

dan

$$
a=\frac{\sum y-b_{1} \sum x_{1}-b_{2} \sum x_{2}}{n}
$$

\section{Contoh}

Tentukan persamaan regresi linier berganda yang diperoleh dari data pendapatan keluarga per hari $\left(\mathrm{X}_{1}\right)$, jumlah anggota keluarga $\left(\mathrm{X}_{2}\right)$ dan pengeluaran konsumsi keluarga per hari $(\mathrm{Y})$ sebagai berikut, 


\begin{tabular}{|c|c|c|c|}
\hline No & $\begin{array}{c}\text { Pendapatan } \\
\text { Keluarga per } \\
\text { hari }\left(\mathbf{X}_{\mathbf{1}}\right)\end{array}$ & $\begin{array}{c}\text { Jumlah } \\
\text { Anggota } \\
\text { Keluarga } \\
\left(\mathbf{X}_{\mathbf{2}}\right)\end{array}$ & $\begin{array}{c}\text { Pengeluaran } \\
\text { Keluarga per } \\
\text { hari (Y) }\end{array}$ \\
\hline 1 & 60 & 3 & 19 \\
2 & 70 & 4 & 20 \\
3 & 60 & 3 & 14 \\
4 & 40 & 3 & 10 \\
5 & 70 & 5 & 22 \\
6 & 80 & 6 & 23 \\
7 & 60 & 4 & 17 \\
8 & 40 & 2 & 15 \\
9 & 20 & 3 & 7 \\
10 & 100 & 7 & 23 \\
\hline
\end{tabular}

Penyelesaian

\begin{tabular}{|c|c|c|c|c|c|c|c|c|c|}
\hline No & $\mathbf{X}_{\mathbf{1}}$ & $\mathbf{X}_{\mathbf{2}}$ & $\mathbf{Y}$ & $\mathbf{X}_{\mathbf{1}}{ }^{\mathbf{2}}$ & $\mathbf{X}_{\mathbf{2}}{ }^{2}$ & $\mathbf{Y}^{\mathbf{2}}$ & $\mathbf{X}_{\mathbf{1}} \mathbf{X}_{\mathbf{2}}$ & $\mathbf{X}_{\mathbf{1}} \mathbf{Y}$ & $\mathbf{X}_{\mathbf{2}} \mathbf{Y}$ \\
\hline 1 & 60 & 3 & 19 & 3600 & 9 & 361 & 180 & 1140 & 57 \\
\hline 2 & 70 & 4 & 20 & 4900 & 16 & 400 & 280 & 1400 & 80 \\
\hline 3 & 60 & 3 & 14 & 3600 & 9 & 196 & 180 & 840 & 42 \\
\hline 4 & 40 & 3 & 10 & 1600 & 9 & 100 & 120 & 400 & 30 \\
\hline 5 & 70 & 5 & 22 & 4900 & 25 & 484 & 350 & 1540 & 110 \\
\hline 6 & 80 & 6 & 23 & 6400 & 36 & 529 & 480 & 1840 & 138 \\
\hline 7 & 60 & 4 & 17 & 3600 & 16 & 289 & 240 & 1020 & 68 \\
\hline 8 & 40 & 2 & 15 & 1600 & 4 & 225 & 80 & 600 & 30 \\
\hline 9 & 20 & 3 & 7 & 400 & 9 & 49 & 60 & 140 & 21 \\
\hline 10 & 100 & 7 & 23 & 10000 & 49 & 529 & 700 & 2300 & 161 \\
\hline Total & 600 & 40 & 170 & 40600 & 182 & 3162 & 2670 & 11220 & 737 \\
\hline
\end{tabular}


Dari table tersebut kemudian diperoleh,

$$
\begin{aligned}
& b_{1}=\frac{\sum x_{1} y \sum x_{2}{ }^{2}-x_{2} y \sum x_{1} x_{2}}{\sum x_{1}{ }^{2} \sum x_{2}{ }^{2}-\left(\sum x_{1} x_{2}\right)^{2}}=0,25 \\
& b_{2}=\frac{\sum x_{2} y \sum x_{1}{ }^{2}-x_{1} y \sum x_{1} x_{2}}{\sum x_{1}{ }^{2} \sum x_{2}{ }^{2}-\left(\sum x_{1} x_{2}\right)^{2}}=-0,47 \\
& a=\frac{\sum y-b_{1} \sum x_{1}-b_{2} \sum x_{2}}{n}=3,88
\end{aligned}
$$

Sehingga diperoleh persamaan regresi linier berganda,

$$
Y=3,88+0,25 X_{1}-0,47 X_{2}
$$

\section{LATIHAN}

1. Tabel berikut menyajikan jumlah produksi barang " $Z$ " oleh sebuah perusahaan Zyu Corp.

\begin{tabular}{|c|c|}
\hline Tahun & Produksi (ton) \\
\hline 2009 & 3,0 \\
\hline 2010 & 2,0 \\
\hline 2011 & 4,0 \\
\hline 2012 & 5,5 \\
\hline 2013 & 6,0 \\
\hline 2014 & 5,0 \\
\hline 2015 & 7,0 \\
\hline 2016 & 8,0 \\
\hline
\end{tabular}

a. Tentukan persamaan garis trend linear dengan metode kuadrat terkecil.

b. Perkirakan jumlah produksi pada tahun 2019 dan tahun 2020

2. Sebuah penelitian dilakukan terhadap salah satu UMKM di bidang perikanan untuk mengetahui apakah 
ada pengaruh makanan ikan (tiap hari dalam seminggu) $\left(X_{1}\right)$ dan panjang ikan $(\mathrm{mm})\left(\mathrm{X}_{2}\right)$ terhadap berat ikan (kg) (Y) di Desa Tani Tambak Raya Sejahtera. Diperoleh data sebagai berikut

\begin{tabular}{|c|c|c|c|}
\hline No & $\mathbf{X}_{\mathbf{1}}$ & $\mathbf{X}_{\mathbf{2}}$ & $\mathbf{Y}$ \\
\hline 1 & 8 & 125 & 37 \\
\hline 2 & 10 & 137 & 41 \\
\hline 3 & 7 & 100 & 34 \\
\hline 4 & 12 & 122 & 39 \\
\hline 5 & 9 & 129 & 40 \\
\hline 6 & 10 & 128 & 42 \\
\hline 7 & 7 & 98 & 38 \\
\hline 8 & 8 & 103 & 42 \\
\hline 9 & 11 & 130 & 40 \\
\hline 10 & 8 & 95 & 36 \\
\hline 11 & 10 & 115 & 41 \\
\hline 12 & 8 & 105 & 38 \\
\hline
\end{tabular}

a. Tentukan persamaan regresi linier berganda dari data di atas.

b. Buktikan apakah ada pengaruh yang signifikan antara makanan ikan dan panjang ikan terhadap berat ikan. 


\section{BAB IX}

\section{PENGUIIAN ANOVA}

\section{A. PENDAhULUAN}

Analisis varians klasifikasi tunggal atau ANOVA satu jalan (One Way ANOVA) digunakan untuk menguji hipotesis komparatif rata-rata $k$ sampel, bila pada setiap sarnpel hanya terdiri atas satu kategori.

\section{B. PENYAJIAN MATERI}

Langkah-langkah pengujian One Way ANOVA adalah sebagai berikut :

Langkah 1 : Menentukan $\mathrm{H}_{0}$ dan $\mathrm{H}_{1}$

$\mathrm{H}_{0}$ : tidak terdapat perbedaan diantara rata-rata beberapa populasi.

$\mathrm{H}_{1} \quad$ : terdapat perbedaan dengan rata-rata populasi lainnya.

\section{Langkah 2 : Menentukan Daerah Penerimaan $\mathbf{H}_{\mathbf{0}}$ dan $\mathbf{H}_{\mathbf{1}}$}

Pengujian hipotesis metode ANOVA menggunakan distribusi $\mathrm{F}$, yang mempunyai sifat :

- Kontinyu

- Bernilai nol atau positif

- Distribusi menceng ke kanan

- Tidak pernah memotong sumbu datar

Jika digambarkan maka sebagai berikut, 


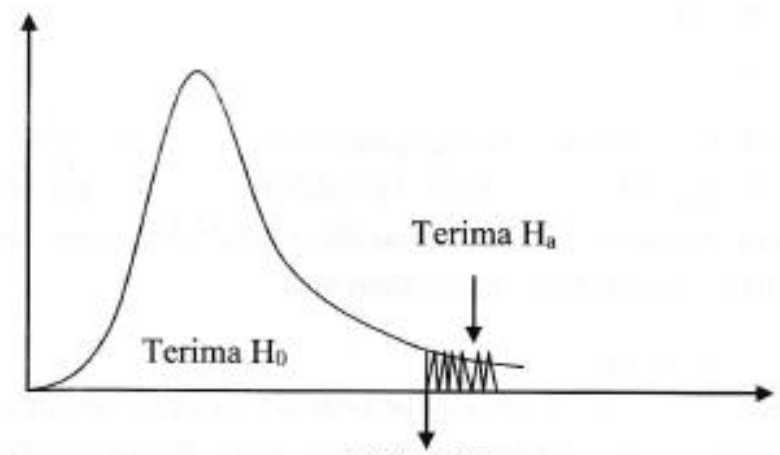

Titik kritis

Titik kritis didapatkan dari table $\mathrm{F}$, dengan memperhatikan :

1. Taraf Nyata $(\alpha)$ atau level of significance

Taraf nyata menunjukkan besarnya kemungkinan penerimaan $\mathrm{H}_{0}$. Besarnya taraf nyata ditentukan oleh peneliti berkisar antara $25 \%$ sampai $0,1 \%$. Namun secara umum peneliti menggunakan $5 \%$.

2. Derajat Bebas atau degree of freedom $(d f)$

Derajat bebas terdiri dari :

a. Numerator $=k-1$

b. Denominator $=k(n-1)$

Dengan

$k=$ jumlah kolom

$n=$ jumlah elemen tiap kolom

\section{Langkah 3 : Menentukan nilai Statistik Uji}

Nilai statistic uji atau F-ratio atau F-test dihitung dengan menggunakan rumus : 
$\begin{aligned} F-\text { ratio } & =\frac{\text { variancebetween sample }}{\text { variance within sample }} \\ & =\frac{\text { explained variation }}{\text { residual variation }}\end{aligned}$

Dengan menggunakan table ANOVA berikut :

\begin{tabular}{|c|c|c|c|c|}
\hline Sumber & Sum of Squares & DF & $\begin{array}{c}\text { Mean } \\
\text { Square }\end{array}$ & F-ratio \\
\hline $\begin{array}{c}\text { Between- } \\
\text { columns }\end{array}$ & $n \sum_{i=1}^{c}\left(\bar{x}_{i}-\bar{x}\right)^{2}$ & $k-1$ & SScols/DF & $\frac{M S_{c o l s}}{M S_{r e s}}$ \\
\hline Residual & $\sum_{i=1}^{c} \sum_{t=1}^{n}\left(x_{i t}-\overline{x_{i}}\right)^{2}$ & $k(n-1)$ & SSres/DF & \\
\hline
\end{tabular}

Langkah 4 : Membandingkan nilai F-ratio dengan daerah penerimaan $\mathrm{H}_{0}$ dan $\mathrm{H}_{1}$.

Jika F-ratio lebih kecil dari titik kritis maka $\mathrm{H}_{0}$ diterima dan jika F-ratio lebih besar dari titik kritis maka $\mathrm{H}_{0}$ ditolak.

\section{Langkah 5 : Simpulan}

- Apabila $\mathrm{H}_{0}$ diterima, artinya menerima hipotesis yang menyatakan bahwa tidak terdapat perbedaan diantara rata-rata beberapa populasi.

- Apabila $\mathrm{H}_{0}$ ditolak, artinya menolak hipotesis yang rnenyatakan bahwa terdapat perbedaan dengan rata-rata populasi lain. 
Contoh

Untuk meneliti apakah terdapat perbedaan tingkat penjualan sales yang berpendidikan SMP, SMA dan S1 maka diambilah sampel sebagai berikut :

\begin{tabular}{|c|c|}
\hline Pendidikan & Tingkat Penjualan \\
\hline SMP & 47 \\
SMP & 53 \\
SMP & 49 \\
SMP & 50 \\
SMP & 46 \\
SMA & 55 \\
SMA & 54 \\
SMA & 58 \\
SMA & 61 \\
SMA & 52 \\
S1 & 54 \\
S1 & 50 \\
S1 & 51 \\
S1 & 51 \\
S1 & 49 \\
\hline
\end{tabular}

Penyelesaian :

\begin{tabular}{|c|c|c|}
\hline SMP & SMA & S1 \\
\hline 47 & 55 & 54 \\
53 & 54 & 50 \\
49 & 58 & 51 \\
50 & 61 & 51 \\
46 & 52 & 49 \\
\hline
\end{tabular}




\begin{tabular}{|l|l|l|}
\hline$\overline{x_{1}}=49$ & $\overline{x_{2}}=56$ & $\overline{x_{3}}=51$ \\
\hline
\end{tabular}

\section{Langkah 1 : Menentukan $\mathrm{H}_{0}$ dan $\mathrm{H}_{1}$}

$\mathrm{H}_{0} \quad$ : tidak terdapat perbedaan tingkat penjualan berdasarkan pendidikan

$\mathrm{H}_{1} \quad$ : terdapat perbedaan tingkat penjualan berdasarkan pendidikan

\section{Langkah 2 : Menentukan Daerah Penerimaan $\mathrm{H}_{0}$ dan $\mathrm{H}_{1}$}

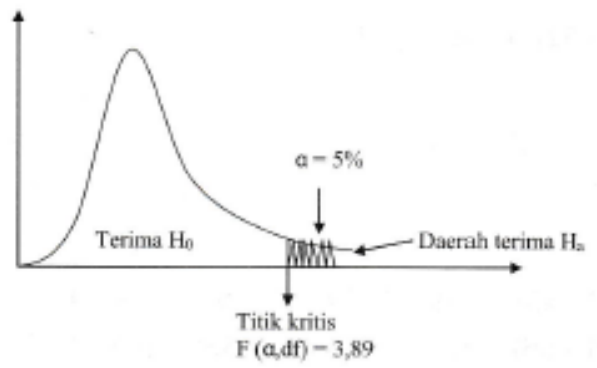

Titik kritis dicari pada table $\mathrm{F}$ dengan memperhatikan :

1. Taraf nyata $(\alpha)=5 \%$

2. Derajat bebas atau degree of freedom (df)

a. Numerator $=k-1=3-1=2$

b. Denominator $=k(n-1)=3(5-1)=12$

Nilai $F(5 \%, 2,12)$ pada table $F=3,89$, sehingga

- Daerah penerimaan $\mathrm{H}_{0}$ adalah $\mathrm{F}<3,89$

- Daerah penerimaan $\mathrm{H}_{1}$ adalah $\mathrm{F}>3,89$

\section{Langkah 3 : Menentukan nilai Statistik Uji}

Nilai statistic uji atau F-ratio dicari dengan menggunakan rumusan, 


$$
\begin{aligned}
\bar{x}= & \frac{\overline{x_{1}}+\overline{x_{2}}+\overline{x_{3}}}{3} \\
= & \frac{49+56+51}{3}=52 \\
S S_{\text {cols }} & =n \sum_{i=1}^{c}\left(\overline{x_{i}}-\bar{x}\right)^{2} \\
& =5\left((49-52)^{2}+(56-52)^{2}+(51-52)^{2}\right) \\
& =5(9+36+1) \\
& =230 \\
S S_{\text {res }} & =\sum_{i=1}^{c} \sum_{t=1}^{n}\left(x_{i t}-\bar{x}_{i}\right)^{2} \\
& =94
\end{aligned}
$$

Tabel ANOVA

\begin{tabular}{|c|c|c|c|c|}
\hline Sumber & Sum of Squares & DF & $\begin{array}{c}\text { Mean } \\
\text { Square }\end{array}$ & F-ratio \\
\hline $\begin{array}{c}\text { Between- } \\
\text { columns }\end{array}$ & 230 & 2 & $\begin{array}{c}\text { SScols/DF } \\
=230 / 2 \\
=115\end{array}$ & $\begin{array}{c}\frac{M S_{\text {cols }}}{M S_{\text {res }}} \\
=\frac{115}{7,83} \\
=14,69\end{array}$ \\
\hline Residual & 94 & 12 & $\begin{array}{c}\text { SSres/DF } \\
=94 / 12 \\
=7,83\end{array}$ & \\
\hline
\end{tabular}

Langkah 4 : Membandingkan nilai F-ratio dengan daerah penerimaan $\mathrm{H}_{0}$ dan $\mathrm{H}_{1}$. 
Karena F-ratio $=14,69$ dan titik kritis $=3,89$ maka F-ratio $(14,69)$ lebih besar dari titik kritis $(3,89)$ maka $\mathrm{H}_{0}$ ditolak.

\section{Langkah 5 : Simpulan}

Karena $\mathrm{H}_{0}$ ditolak maka $\mathrm{H}_{1}$ diterima yang artinya terdapat perbedaan tingkat penjualan berdasarkan pendidikan.

\section{LATIHAN}

1. Suatu penelitian dilakukan untuk mengetahui pengaruh perbedaan kartu kredit terhadap penggunaannya. Diperoleh data jumlah uang yang dibelanjakan ibu rumah tangga dengan menggunakan kartu kredit (dalam dollar) sebagai berikut :

\begin{tabular}{|c|c|c|}
\hline BCA & CITI & Mandiri \\
\hline 13 & 8 & 19 \\
\hline 12 & 7 & 20 \\
\hline 14 & 10 & 15 \\
\hline 15 & 19 & 18 \\
\hline 16 & 11 & 19 \\
\hline
\end{tabular}

Ujilah dengan $\alpha=5 \%$, apakah terdapat pengaruh perbedaan kartu kredit pada penggunaannya?

2. Terdapat 4 strategi dalam penjualan sebuah produk dan 3 level sales. Berikut data hasil penjualan produk tersebut pada strategi dalam pemasaran dan level sales. 


\begin{tabular}{|c|c|c|c|c|}
\hline & Strategi 1 & Strategi 2 & Strategi 3 & Strategi 4 \\
\hline 1 & 4 & 8 & 7 & 6 \\
\hline 2 & 6 & 12 & 3 & 5 \\
\hline 3 & 4 & - & - & 5 \\
\hline
\end{tabular}

Apakah keempat strategi pemasaran tersebut memberikan rata-rata penjualan yang sama?

Uji pendapat tersebut dengan taraf nyata $5 \%$ 


\section{DAFTAR PUSTAKA}

Anto Dajan. 1986. Pengantar Metode Statistik - Jilid 2. Jakarta LP3ES

Prasojo, Bayu Hari. 2019. Pengantar Statistik untuk Manajemen. Sidoarjo. UMSIDA Press

Suharyadi, Purwanto. 2007. Statistika untuk Ekonomi dan Keuangan Modern buku 1 dan 2. Jakarta. Salemba Empat.

Sujarweni, V Wiratna. 2015. Statistik untuk Bisnis dan Ekonomi. Yogyakarta. Pustaka Baru Press.

Supranto. 2008. Statistik Teori dan Aplikasi. Jilid 1 dan 2. Jakarta. Erlangga.

Walpole, Ronald E. (1995). Pengantar Statistika. Jakarta. PT. Gramedia Pustaka Utama. 


\section{BIODATA PENULIS}

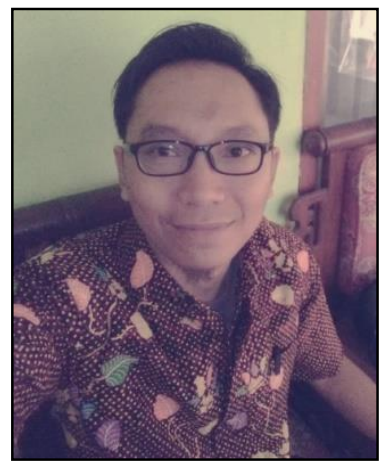

Bayu Hari Prasojo, S.Si., M.Pd. lahir di Pasuruan, 27 Maret 1981. Lulus Sarjana Matematika Universitas Brawijaya Malang tahun 2003, melanjutkan studi S2 di Prodi Pendidikan Matematika Program Pascasarjana Universitas Negeri Surabaya lulus tahun 2015.. Karir pengajaran dimulai tahun 2015 di Prodi Manajemen Fakultas Ekonomi dan Bisnis Universitas Muhammadiyah

Sidoarjo. Penulis terlibat dalam penelitian dan pengabdian kepada masyarakat baik didanai oleh Ristekdikti, Internal maupun Mandiri tentang Pendidikan Matematika, Matematika Bisnis dan Sosial Humaniora.

Novia Ariyanti, S.Si., M.Pd. lahir di Surabaya, 10 Nopember 1983. Lulus Sarjana Matematika Universitas Negeri Surabaya tahun 2007 dengan gelar S.Si. Penulis melanjutkan studi S2 di Prodi Pendidikan Matematika Program Pascasarjana Universitas Negeri Surabaya lulus tahun 2014 dengan gelar M.Pd. Karir pendidikan dan pengajaran dimulai tahun 2015 di fakultas Teknik Prodi Informatika Universitas Muhammadiyah Sidoarjo.

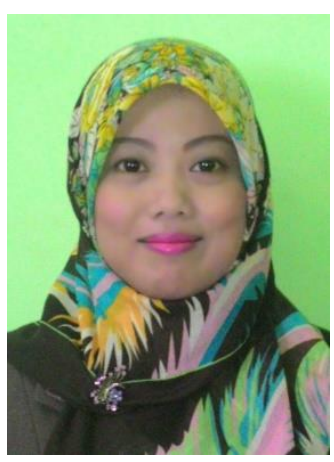
Selain pengajaran, penulis juga ikut berperan serta dalam kegiatan penelitian dan pengabdian. Penulis juga aktif dalam mengikuti kegiatan-kegiatan penunjang akademik seperti seminar, workshop/ lokakarya, pelatihan dan kegiatan akademik lainnya. 
